\title{
MuTAÇÃO CONSTITUCIONAL COMO EVOLUÇÃO NORMATIVA OU PATOLOGia CONSTITUCIONAL? TeMPo E Direito À LuZ dA HeRMenÊUTICA-FilosóficA
}

\author{
ANDERSON VICHINKESKI TEIXEIRA ${ }^{\dagger}$ \\ JOÃO LUIZ ROCHA DO NASCIMENTO ${ }^{\dagger \dagger}$
}

RESUMO: O presente artigo busca analisar a relação entre tempo e direito, especialmente com base na matriz teórica de François Ost, concentrando o enfoque na natureza e nos limites da mutação constitucional. Mais especificamente, o problema central da pesquisa concerne à mutação constitucional informal e seus possíveis limites. Nesse sentido, pretende-se verificar como o referido fenômeno, diante da hipótese de que ocorra sem controles, pode resultar na submissão da jurisdição, em especial a constitucional, ao paradigma da filosofia da consciência, uma vez que as decisões carregadas de excessiva subjetividade atribuem ao julgador o poder de decidir como quer, conferindo à norma o sentido que bem entende, o que termina por, em última instância, fragilizar a Constituição, o princípio democrático e a

\footnotetext{
† Doutor em Teoria e História do Direito pela Università degli Studi di Firenze, Itália, com estágio de pesquisa doutoral junto à Faculdade de Filosofia da Université Paris Descartes-Sorbonne, França. Estágio pós-doutoral junto à Università degli Studi di Firenze. Mestre em Direito do Estado pela Pontifícia Universidade Católica do Rio Grande do Sul (PUC-RS). Professor do Programa de Pós-Graduação em Direito da Universidade do Vale do Rio dos Sinos (UNISINOS). Advogado.

† Doutorando e Mestre em Direito Público pela Universidade do Vale do Rio dos Sinos (UNISINOS). Especialista em Direito Constitucional pela Universidade Federal do Piauí (UFPI) e em Direito Processual pela Universidade Federal de Santa Catarina (UFSC). Juiz do Trabalho do Tribunal Regional do Trabalho da 22ª Região e Titular da Vara Federal do Trabalho de Floriano/PI. Professor Assistente do Curso de Direito da Universidade Estadual do Piauí (UESPI). Professor da Pós-Graduação em Direito do Trabalho e Processo do Trabalho da Universidade Estácio de Sá/Centro de Ensino Unificado de Teresina (CEUT). Professor da Pós-Graduação em Direito do Trabalho Constitucional do Instituto de Ensinos Empresariais (IEMP), de Teresina/PI. Membro do Grupo de Pesquisa Hermenêutica e Teoria da Decisão, da UNISINOS.
} 
separação de poderes. $\mathrm{O}$ método empregado é o hermenêuticofenomenológico, de modo que o objeto central da pesquisa - i.e., o fenômeno da mutação constitucional - possa ser abordado e reconstruído pelo intérprete com base na sua doutrina de origem, em contraste com a atual realidade constitucional brasileira.

PAlAVRAS-CHAVE: Hermenêutica Constitucional; Mutação Constitucional; Tempo e Direito.

\begin{abstract}
The article aims to analyze the relationship between time and law, especially based on the theoretical work of François Ost, concentrating the focus on the nature and limits of the constitutional mutation. More specifically, the central problem of the research concerns the informal constitutional mutation and its possible limits. In this sense, it is sought to verify how the abovementioned phenomenon, given the hypothesis that it occurs without controls, can result in the submission of the jurisdiction, especially the constitutional one, to the paradigm of the philosophy of the conscience, since the decisions loaded with excessive subjectivity allows the judge the power to decide as he wishes, conferring to the norm the meaning he understands, which ultimately ends up weakening the Constitution, the democratic principle and the separation of powers. The method employed is the hermeneutic-phenomenological, so that the central object of the research - i.e., the phenomenon of constitutional mutation - can be approached and reconstructed by the interpreter based on its doctrine of origin, in contrast to current Brazilian constitutional reality.
\end{abstract}

KEYWORDS: Constitutional Interpretation; Constitutional Mutation; Time and Law. 


\section{SUMÁRIO:}

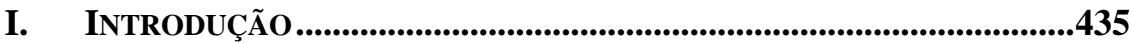

II. A RELAÇÃO ENTRE TEMPO E DIREITO .........................................437

III. ESTABILIDADE CONSTITUCIONAL E MECANISMOS DE MUDANÇA...440

1. Breve teoria da mutação constitucional: conceitos e significados

2. A relação texto e norma......................................................444

3. Limites à mutação constitucional ..............................................446

IV. A MUTAÇÃo CONSTITUCIONAL E OS PARADIGMAS DA FILOSOFIA.450

1. A ausência de limites à mutação constitucional como submissão à Filosofia da Consciência.

2. Superando os limites da mutação constitucional: evolução normativa ou patologia constitucional?

V. CONSIDERAÇÕES FINAIS

VI. REFERÊNCIAS

\section{TABLE OF CONTENTS:}

I. INTRODUCTION

II. THE RELATION BETWEEN TIME AND LAW .........................................437

III. CONSTITUTIONAL STABILITY AND MECHANISMS OF CHANGE.........440

1. Brief theory of constitutional change: concepts and meanings

2. The text and norm relationship ...............................................444

3. Limits to constitutional change.................................................446

IV. The CONSTITUTIONAL CHANGE

AND THE PARADIGMS OF PHILOSOPHY 450

1. The absence of limits to constitutional change as a submission to the Philosophy of Consciousness...........452

2. Overcoming the limites of constitutional change: normative evolution or constitutional pathology? ................458

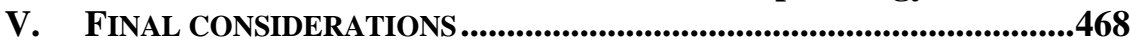

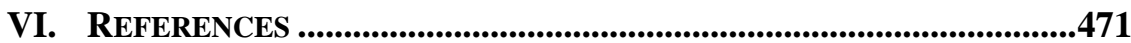




\section{INTRODUÇÃO}

Houve, entre os helenos, num tempo muito distante, quem defendesse que as leis deveriam ser eternas. Amplamente notória é a história, contada por Plutarco (884 a.C.), sobre o legislador Licurgo. Segundo consta, tal qual o Deus impiedoso e vingativo do Velho Testamento, Licurgo, ao concluir as leis de Esparta, regozijou-se e as considerou tão perfeitas que as pretendeu imortais, de sorte a evitar que, no futuro, fossem alteradas. Para tanto, utilizou-se de um estratagema: reunir o provo em praça pública e não medir esforços em demonstrar que as leis por ele elaboradas proporcionavam uma vida boa e virtuosa aos espartanos. Alertou, contudo, que havia uma questão a ser resolvida, e sobre a qual nada podia declarar até que empreendesse uma viagem à cidade de Delfos, onde faria uma consulta ao famoso oráculo de Apolo. Antes de partir, obteve dos reis e do povo o juramento de que suas leis permaneceriam inalteradas até seu regresso.

Chegando ao destino, dirigiu-se ao oráculo e, após a consulta, obteve do próprio Apolo a aprovação de suas leis, tendo o deus grego destacado que eram realmente muito boas e que, se assim fossem conservadas, fariam de Esparta um reino de glória. Em seguida, tratou de comunicar ao povo espartano o resultado da consulta e decidiu não mais regressar, permanecendo em Delfos, onde morreria por vontade própria, pois com isso garantiria que os cidadãos da cidade jamais seriam absolvidos do juramento, de modo que as leis de Esparta, tal qual um diamante, se mantiveram inalteradas por mais de 500 anos. $^{1}$

${ }^{1}$ Licurgo agiu, em parte, como Kronos, o deus do tempo, na mitologia grega, e exigiu dos cidadãos, mediante juramento, que não alterassem a Constituição da Lacedemônia (região da antiga Grécia cuja capital era a cidade de Esparta) e mantivessem viva a memória do tempo. Com isso, bloqueou qualquer possibilidade de passagem para o futuro. Acorrentou a vida dos espartanos no presente com um pé fincado no passado, que era o tempo do direito de Licurgo. Operou-se ali a primeira forma de recusa do tempo, no sentido de se opor a qualquer sorte de mudança, o que François Ost chama de "nostalgia da eternidade: o refúgio em algum erzats de perenidade, ilusória compensação para a dura realidade de uma condição finita e mortal". OST, François. $\mathbf{O}$ Tempo do Direito. Bauru, SP: Edusc, 2005, p. 25. Essa ilusória compensação teve um alto custo para Licurgo: a própria vida em troca de uma pretendida eternidade para as leis que forjou. Mesmo assim, elas não se fizeram eternas, dado que a ruptura, da mesma forma que se deu com as duas medidas do tempo (passado e presente), veio ocorrer, como conta Plutarco, quinhentos anos depois, com a ascensão do rei Agis, filho de Arquidamo, em cujo reinado as leis licurguianas, acerca das quais não havia 
É razoável a compreensão de que Licurgo - e nem se poderia exigir dele algo diferente -, no período histórico em que elaborou as leis, não pudesse imaginar que a vida e a sociedade poderiam, no futuro, tornarse mais complexas, disso resultando transformações sociais incompatíveis com a imutabilidade das leis. Conquanto devam brilhar e iluminar os homens com o ideal (a ser perseguido e não somente enunciado) de uma vida boa, as leis, mormente as Constituições, não são (nem poderiam ser) eternas como os diamantes. ${ }^{2}$ Mesmo os textos constitucionais mais estáveis, a exemplo da primeira e única Constituição estadunidense, não são blindados contra mudanças, pois, promulgada em 1787, foi, ao longo de todo esse tempo, alterada, embora não passem de 27 as emendas que modificaram a versão original; ademais, 10 das 27 emendas foram editadas no mesmo dia, em 25 de setembro de 1789, pouco mais de dois anos após a promulgação do texto constitucional. Estabilidade, portanto, não é sinônimo de imutabilidade.

Se, por um lado, o modelo estabilidade é o paradigma almejado em termos de constituições escritas, a história registra inúmeros casos de constituições efêmeras, algumas durando um pouco mais do que uma estação chuvosa. A Constituição brasileira de 1934, por exemplo, vigeu por menos de quatro anos. Hoje, após a restauração do regime democrático em 1988, vive-se uma estabilidade constitucional de quase 30 anos, embora a maioria das promessas assumidas pelo Constituinte ainda se encontrem pendentes de realização.

De fato, a Constituição de 1988 vem experimentando relativa estabilidade, se comparada com as cinco constituições republicanas anteriores, sendo, depois de passado um quarto de século, a segunda constituição brasileira mais duradoura, só perdendo para a de 1891, o que provavelmente será superado, porquanto nada indica que esse processo possa ser interrompido, não obstante as tentativas pontuais de desestabilização ${ }^{3}$ via procedimento formal (emendas, "constituintes

marca e nem aparência de iniquidade ou de injustiça, foram, por força das necessidades cambiantes, modificadas.

${ }^{2}$ A rigor, nem os diamantes são eternos. Embora dotados de constituição rígida e forte o bastante que lhes conferem uma dureza capaz de atravessar séculos, não há garantia de que durem por toda eternidade, mesmo porque um testemunho de tal ordem seria impossível, dado que tudo na vida passa. A eternidade dos diamantes, presente no imaginário das pessoas, soa, assim, mais como um recurso poético ou metafórico do que como uma verdade cientifica.

${ }^{3}$ Por vezes surge a proposta de uma "Constituinte específica" para tratar de determinada matéria, como no caso, relativamente recente, da reforma política. 
parciais") ou informal, como no caso das mutações constitucionais operadas pelo Supremo Tribunal Federal, em especial, como se pode ilustrar com as propostas representadas pelos votos dos Ministros Gilmar Mendes e Eros Grau, no âmbito da Reclamação Constitucional n. 4.3355/AC. Trata-se de um entendimento que, se prevalecer, pode representar uma ruptura da ordem constitucional, com a agravante de abrir uma perigosa porta para a tendência de fazer do STF, sem qualquer autorização legislativa, um Poder Constituinte Derivado permanente isso sem falar do espezinhamento do princípio democrático, pois subestima o princípio fundante da soberania popular e viola a cláusula pétrea da separação de poderes.

É no âmago dessa problemática, guiado pela perspectiva da relação entre tempo e direito, especialmente com base na matriz teórica de François Ost, que o presente trabalho objetiva, em termos gerais, fazer uma análise acerca da natureza e dos limites da mutação constitucional. Para tanto, pretende-se verificar como o fenômeno da mutação, diante da hipótese de que ocorra sem controles, pode resultar na submissão da jurisdição, em especial a constitucional, ao paradigma da filosofia da consciência, uma vez que as decisões carregadas de excessiva subjetividade atribuem ao julgador o poder de decidir como quer, conferindo à norma o sentido que bem entende, fragilizando, derradeiramente, a Constituição, o princípio democrático e a separação de poderes.

\section{A RELAÇÃo ENTRE TEMPO E Direito}

É possível estabelecer uma relação simbólica entre uma Constituição e os dois famosos poemas atribuídos ao poeta Homero. Ora, enquanto na Ilíada se relata a guerra e a conquista de Tróia, feito em torno do qual as nações gregas se uniram para resgatar a autoestima e a honra violada do provo grego, a promulgação da Constituição brasileira de 1988, em torno da qual o povo, por delegação, se uniu, representou a derrocada das muralhas do medo e do horror erguidas pelo regime autoritário, a reconquista da democracia e o retorno da cidadania tão bem traduzidos no gesto e nas palavras de Ulysses Guimarães, quando declarou que o

Idêntica tentativa ocorrera em 1994, quando da discussão da Revisão Constitucional prevista no art. $3^{\circ}$ do ADCT. Embora se possa falar da impropriedade do emprego da expressão "Constituinte específica", uma vez que a inicialidade é característica elementar do Poder Constituinte, verificar-se-ia nesses casos uma típica revisão constitucional, em vez de pontual reforma constitucional. 
Congresso Nacional promulgara uma Constituição Cidadã.

Superada a primeira etapa, a Constituição precisa ser protegida contra os predadores internos e externos, sem o que não poderá cumprir o compromisso de assegurar vida boa aos que a constituíram. E não há metáfora que melhor represente a necessidade de guarda de uma Constituição do que o episódio "Canto das Sereias" do segundo e mais famoso poema homérico: a Odisséia. Após a vitória, Odisseu (Ulisses, para os ocidentais) fez a viagem de volta a Ítaca, ilha grega sobre a qual reinava, para cumprir promessa feita a Penélope, esposa e rainha, de voltar para casa. Embora passasse por uma série de provações enquanto navegava pelo Egeu e o Mediterrâneo, talvez não exista na literatura exemplo de adversidade maior do que aquela enfrentada por Odisseu: fiel ao compromisso de retornar ao lar, teve que resistir à sedução do irresistível canto das sereias, determinando aos seus homens que o amarrassem no mastro do navio, que todos tapassem os ouvidos com cera e que ignorassem qualquer ordem contrária, por mais intenso que fosse $o$ desespero de ceder.

Nesse mesmo sentido, preservar a estabilidade da Constituição é resistir ao canto diário das sereias e suas tentativas de fragilizá-la e impedir que se cumpram as promessas de modernidade assumidas. Contudo, como já registrado, estabilidade não é sinônimo de imutabilidade, nem estabilidade e mudança constitucional são irmãs antípodas, muito menos primas distantes. Podem até passar a ideia de que há um paradoxo entre elas, mas isso é apenas aparente. De fato, a relação entre tempo e direito é marcada por uma constante tensão decorrente da própria característica de cada um desses elementos.

Enquanto o tempo não para e segue produzindo mudanças, o direito carrega a ideia de constância, sendo no interior dessa tensão que ambos se movimentam: o tempo tem a força de transformar o próprio direito, de pautá-lo, de instituí-lo, daí porque vivem em estado permanente de articulação. Sem mudança não há estabilidade, mas petrificação, o que é inviável diante das contingências representadas pela realidade cambiante de uma sociedade pós-moderna e de risco. Ademais, as mudanças são necessárias à própria oxigenação da estabilidade, sem o que correria, no limite, o perigo de uma ruptura total. Entre as duas categorias há, portanto, uma relação de interdependência recíproca, já que, como diz François Ost, estabilidade significa, simultaneamente, memória (ligada ao passado) e projeto (voltado para o futuro), algo "nem eterno, nem perecível".4

As Constituições precisam de oxigênio para sobreviver, sendo, em

${ }^{4}$ OST, François. O Tempo do Direito. Bauru, SP: Edusc, 2005, p. 19/24. 
grande parte das vezes, fornecido pelas necessidades de mudanças. As Constituições mudam para que permaneçam constituindo, até porque nem sempre o direito pauta a sociedade, pois esta também tem ingerência sobre o direito, o que é feito levando-se em conta o tempo e um dado contexto histórico.

Assim, quando se fala na estabilidade de uma lei, de determinada norma ou da própria Constituição, não se pode perder de vista a necessária relação entre tempo e direito. No direito romano já era possível identificar essa relação traduzida na velha sentença latina: tempus regit actum. O direito é filho do tempo, possuindo, assim, um sentido temporal. Portanto, estabilidade e mudança são filhos dessa relação.

François Ost, ao invocar as figuras da Temperantia (Temperança, a sabedoria do tempo) e da Justitia (Justiça, a sabedoria do direito), lembra que a relação entre tempo e direito (que ele chama de justo) vem dos gregos. ${ }^{5}$ E o que é o tempo? Enquanto o direito, diz Ost, tem como principal função contribuir para a instituição do social, o tempo "é uma instituição social, antes de ser um fenômeno físico e uma experiência psíquica" ${ }^{\prime}$, resultando dessa aproximação uma interação dialética, um vínculo entre a temporalização social do tempo e a instituição jurídica da sociedade, não sendo possível dizer o direito senão dando o tempo. ${ }^{7}$

François Ost esclarece que toda a dialética temporal se opera no presente $^{8}$, que é a justa medida dos tempos misturados, cuja temporalização no direito se dá em quatro dimensões distintas:

Lado do passado: a memória e o perdão; lado do futuro: a promessa e a retomada da discussão. A memória [...] liga o passado, garantindo-lhe um registro, uma fundação e uma transmissão. O perdão, [...] desliga o passado, imprimindo-lhe um sentido novo, portador de futuro [...]. A promessa, [...] liga

${ }^{5}$ OST, François. O Tempo do Direito. Bauru, SP: Edusc, 2005, p. 12

${ }^{6}$ OST, François. O Tempo do Direito. Bauru, SP: Edusc, 2005, 12-13.

7 "Mais precisamente: o direito afeta diretamente a temporalização do tempo, ao passo que, em troca, o tempo determina a força instituinte do direito. Ainda mais precisamente: o direito temporaliza, ao passo que o tempo institui. Trata-se, então, de uma dialética profunda e não de relações superficiais que se ligam entre o direito e o tempo. O tempo não permanece exterior à matéria jurídica, como um simples quadro cronológico em cujo seio desenrolaria sua ação; do mesmo modo, o direito não se limita a impor ao calendário alguns prazos normativos, deixando para o restante que o tempo desenrole seu fio. Antes, é muito mais desde o interior que direito e tempo se trabalham mutuamente." OST, François. O Tempo do Direito. Bauru, SP: Edusc, 2005, 13-14.

${ }^{8}$ OST, François. O Tempo do Direito. Bauru, SP: Edusc, 2005, 17-18. 
o futuro, através dos comprometimentos normativos, desde a convenção individual até a Constituição, que é a promessa que a nação fez a si própria. $\mathrm{O}$ questionamento, [...] em tempo útil desliga o futuro, visando operar as revisões que se impõem, para que sobrevivam as promessas na hora da mudança. ${ }^{9}$

Memória, perdão, promessas e questionamentos são as quatro figuras da retemporalização que, na relação tempo e direito, representam a procura da justa medida temporal, aquela que, uma vez encontrada, "se preserva tanto de um tempo petrificado, que não abre nenhuma possibilidade de mudança, quanto de um tempo exageradamente móvel, que não permite nem lugar para a continuidade". ${ }^{10}$ Tal justa medida se opõe às patologias temporais (eternidade, entropia, determinismo e discronia), que assinalam "quatro quedas para aquém de um tempo instituído e significante, quatro regressões ao estado de natureza". ${ }^{11}$ É, assim, por meio dessas temporalidades jurídicas, que a desejada estabilidade e a necessidade de mudanças se articulam e encontram um ponto de equilíbrio.

\section{ESTABILIDADE CONSTITUCIONAL E MECANISMOS DE MUDANÇA}

Segundo Ana Cândida da Cunha Ferraz, pode-se dizer que a Constituição de um Estado, por lhe representar a estrutura fundamental, presume-se estável, o que não significa qualquer aproximação com o sentido de imutabilidade. ${ }^{12}$ Bem ao contrário, anota a autora que "a eficácia das Constituições repousa, justamente, na sua capacidade de enquadrar ou fixar, na ordem constitucional, as vontades e instituições que a sustentam". ${ }^{13}$

${ }_{9}^{9}$ OST, François. O Tempo do Direito. Bauru, SP: Edusc, 2005, p. 17.

${ }^{10}$ OST, François. O Tempo do Direito. Bauru, SP: Edusc, 2005, p. 38.

${ }^{11}$ OST, François. O Tempo do Direito. Bauru, SP: Edusc, 2005, p. 38.

${ }^{12}$ FERRAZ, Ana Cândida da Cunha. Processos Informais de Mudanças da

Constituição: Mutações Constitucionais e Mutações Inconstitucionais. São Paulo, SP: Max Limonad, 1986, p. 5.

${ }^{13}$ FERRAZ, Ana Cândida da Cunha. Processos Informais de Mudanças da

Constituição: Mutações Constitucionais e Mutações Inconstitucionais. São Paulo, SP: Max Limonad, 1986, p. 5. 
A relação entre estabilidade e mudança, como já dito, está na ordem do dia de qualquer ordenamento jurídico, além de integrar o conceito das Constituições tidas como rígidas. Diferentemente das flexíveis, que não exigem maiores solenidades, as rígidas exigem um procedimento mais sofisticado para que as mudanças se operem, destacando-se ainda o fato de que, muitas vezes, elas se reservam um núcleo indisponível, ressalvada a hipótese de ruptura total da ordem que as institui.

No interior dessas Constituições, são fundamentalmente dois os mecanismos de mudança, comumente denominados de formais e informais. Aqueles, de que são exemplos as Emendas à Constituição e a Revisão Constitucional, além de mudar o sentido da norma importam também em alteração do texto; todavia, as alterações informais limitamse à alteração do sentido da norma, sem mudança de texto, tendo na mutação constitucional o maior exemplo. ${ }^{14}$

Qualquer dos mecanismos (formal ou informal) se insere no contexto da relação entre tempo e direito, enquadrando-se, precisamente, na temporalidade jurídica que François Ost denomina de retomada da discussão ou prequestionamento. Para o presente estudo somente interessa o mecanismo informal conhecido como mutação constitucional. ${ }^{15}$

Em suma, o que interessa aqui é oferecer uma resposta à seguinte indagação: se o tempo é instituinte do direito, pois pode contribuir para a mudança/alteração de sentido de uma norma, particularmente de uma Constituição, em que medida a mutação constitucional, no interior da relação tempo e direito, pode ser um (i)legítimo resultado da influência do tempo sobre o direito? Tem ela a função de ligar o futuro ao presente para operar mudanças que possibilitem o cumprimento das promessas assumidas?

\section{Breve teoria da mutação constitucional: conceitos e significados}

É também de Ana Cândida da Cunha Ferraz que se pode tomar o seguinte conceito de mutação constitucional como "reservada a todo e qualquer processo que altere ou modifique o sentido, o significado e o

\footnotetext{
${ }^{14}$ Ana Cândida Ferraz, na obra referenciada, inclui ainda a mutação inconstitucional como exemplo de mecanismo informal de mudança constitucional.

${ }^{15}$ Para um estudo sobre o conceito em si de mutação constitucional, ver o artigo a seguir e sobretudo suas referências bibliográficas: SANTOS, Carlos Victor Nascimento dos. Reconstruindo o conceito de Mutação Constitucional. RECHTD: Revista de
} Estudos Constitucionais, Hermenêutica e Teoria do Direito, Vol. 7, 1, 2015, p. 80-91. 
alcance da Constituição, sem contrariá-la."16 Para que a mutação ocorra, não se podem violar-lhe a letra e o espírito, do contrário se daria a antípoda dessa mutação: uma mudança que, a rigor, é inconstitucional. Konrad Hesse destaca que, no entendimento do Tribunal Constitucional Federal alemão e da doutrina especializada, "uma mutação constitucional modifica, de que maneira for, o conteúdo das normas constitucionais de modo que a norma, conservando o mesmo texto, recebe um significado diferente." 17

Segundo Ferraz, embora as mutações constitucionais se processem de forma diferente dos procedimentos formais comandados pelo Poder Constituinte Derivado, isso não significa que se dispensam justificativa e fundamento jurídico, que "são, em realidade, obra ou manifestação de uma espécie inorganizada do Poder Constituinte, o chamado poder constituinte difuso, na feliz expressão de Burdeau."18 No geral, como características dessa mutação, podem ser apontadas as seguintes: (1) trata-se de um processo informal que (2) ocorre de modo lento e não intencional ${ }^{19}$, (3) envolve uma mudança de interpretação que altera ou modifica o sentido de uma norma constitucional, mas (4) não altera o texto nem contraria a Constituição.

É de se imaginar nessa configuração que a mutação constitucional pode ser tida como um fenômeno próprio das Constituições formais e rígidas, embora nada garanta que as flexíveis estejam a ela imunes. Aliás, isso não faria sentido, dado que, como sequer se preocupam em estabelecer critérios mais rígidos para os procedimentos formais de mudança, não se justificaria qualquer espécie de blindagem no tocante a procedimentos informais.

Recorde-se, para fins de brevíssimo excursus histórico, que a mutação

${ }^{16}$ FERRAZ, Ana Cândida da Cunha. Processos Informais de Mudanças da Constituição: Mutações Constitucionais e Mutações Inconstitucionais. São Paulo, SP: Max Limonad, 1986, p. 10.

${ }^{17}$ HESSE, Konrad. Temas Fundamentais do Direito Constitucional. Trad. Gilmar Ferreira Mendes. São Paulo, SP: Saraiva, 2013, p. 151.

${ }^{18}$ FERRAZ, Ana Cândida da Cunha. Processos Informais de Mudanças da Constituição: Mutações Constitucionais e Mutações Inconstitucionais. São Paulo, SP: Max Limonad, 1986, p. 10.

${ }^{19}$ HESSE, Konrad. Temas Fundamentais do Direito Constitucional. Trad. Gilmar Ferreira Mendes. São Paulo, SP: Saraiva, 2013, p.153, diz que características como duração e caráter inconsciente do processo de mutação constitucional devem ser desprezadas. 
constitucional tem no século XIX, na Alemanha ${ }^{20}$, o seu marco de mais fortes debates iniciais, podendo-se falar em três períodos distintos: o primeiro é anterior à Unificação e se estende até a Constituição de Weimar de 1919, a partir da qual começou o segundo, que se prolongou até o final da II Guerra, quando, com a Lei Fundamental de Bonn, principia-se o terceiro, ainda em curso. Todos os períodos estão representados por teóricos como Paul Laband, Georg Jellinek, Hermann Heller, Rudolph Smend, Hsü Dau-Lin, Karl Loewenstein, Konrad Hesse e, mais recentemente, Peter Häberle, também merecendo menção o espanhol Pablo Lucas Verdú. No Brasil, destacam-se, entre outros, os estudos de Carlos Alberto Lúcio Bittencourt, Raul Machado Horta, Ana Cândida Ferraz, Uadi Lammêgo Bulos, Flávio Quinaud Pedron e Adriano Sant'Ana Pedra. No Supremo Tribunal Federal, o maior entusiasta do tema é o Ministro Gilmar Mendes ${ }^{21}$, seguido de perto por Eros Grau, ministro aposentado.

Segundo Ferraz, tanto o Legislativo quanto o Executivo ${ }^{22}$ e o Judiciário são os órgãos encarregados de promover a mutação constitucional, esclarecendo-se, mais uma vez, que o presente estudo se limita ao exame da mutação constitucional por interpretação judicial no exercício da jurisdição constitucional de competência do Supremo Tribunal Federal.

${ }^{20}$ Carlos Blanco de Morais, professor da Faculdade de Direito de Lisboa, no artigo As mutações constitucionais implícitas e os seus limites jurídicos: autópsias de um acórdão controverso, 2013, afirma que nos EUA, também no século XIX, já havia registros de mutação constitucional. Ilustra como exemplo o caso McCulloch $v$. Maryland (1819). Cf. MORAIS, Carlos Blanco de. As Mutações Constitucionais e os seus Limites Jurídicos: autópsia de um acórdão incontroverso. Jurismat, No. 3, 2013. O tema, contudo, foi sistematizado na Alemanha, a partir da Constituição Imperial de 1871, processo que se repetiu na vigência da Constituição de Weimar e, em seguida, com a Constituição de Bonn, de 1949.

${ }^{21}$ Sobre o tema, ver MENDES, Gilmar Ferreira. O papel do Senado Federal no Controle de Constitucionalidade: um caso Clássico de Mutação Constitucional. Revista de Informação Legislativa, Vol. 41, 162, 2004, 149-168.

22 No caso de mutação constitucional por iniciativa do Executivo, Ana Cândida Ferraz, dentre outros exemplos, destaca a execução das políticas públicas, os atos administrativos e a nomeação de um ministro do Supremo pelo Chefe do Executivo. Isso poderia levar a uma mudança da Constituição diferida no tempo: nos EUA, Rooselvet, como forma de pressionar a aprovação do New Deal, ameaçou mudar toda a composição da Suprema Corte, que vinha sistematicamente rejeitando o programa. Ver FERRAZ, Ana Cândida da Cunha. Processos Informais de Mudanças da Constituição: Mutações Constitucionais e Mutações Inconstitucionais. São Paulo, SP: Max Limonad, 1986. 
Neste particular, interessante é a posição de Peter Häberle, que despreza o conceito de mutação constitucional como uma categoria autônoma, e o faz ao argumento de que interpretar envolve sempre uma mudança no tempo, sempre um processo de mutação. Assim, essa mutação estaria a cargo não somente dos poderes públicos e atores políticos, mas de todos os intérpretes da sociedade aberta. ${ }^{23}$

\section{A relação texto e norma}

Como demonstrado, uma das características da mutação constitucional reside na peculiaridade de que seus efeitos são suportados apenas pela norma, que adquire outro sentido ou significado, restando incólume o texto, daí ser importante que se estabeleçam os contornos de cada uma dessas categorias jurídicas, pontuando-se-lhes as diferenças. Foi em Friedrich Müller, seu aluno e um dos principais teóricos da distinção hermenêutica entre texto e norma, que Konrad Hesse buscou inspiração para desenvolver um estudo acerca dos limites da mutação constitucional.

De fato, ao desenvolver a teoria estruturante do direito, Müller diz que, em termos de teoria da norma, o direito se estrutura em duas categorias: programa da norma (ou programa normativo) e área da norma (ou âmbito da norma). ${ }^{24}$ Por programa normativo deve ser entendido o universo textual, o texto normativo, a sua literalidade. $\mathrm{O}$ âmbito normativo, por sua vez, é o elemento real, a facticidade da norma, o contexto histórico e social, enfim, a realidade social que pode mudar o programa normativo se houver discordância entre ambos, sendo a composição harmônica entre eles uma condição de possibilidade da concretização da norma.

Pela teoria estruturante do direito de Müller, a realidade tem caráter cointegrante, no sentido de que é elemento integrante e constitutivo da própria norma. Assim, não haveria, na relação entre direito e realidade, um enfrentamento entre realidade e norma, dado que a realidade integra o conceito de norma, uma vez que texto e norma se complementam. Em

${ }^{23}$ Ver HÄRBELE, Peter. Hermenêutica Constitucional. A Sociedade Aberta dos Intérpretes da Constituição: contribuição para uma interpretação pluralista e "procedimental" da Constituição. Trad. Gilmar Ferreira Mendes. Porto Alegre, RS: Sérgio Antonio Fabris, 1997.

${ }^{24}$ Ver MÜLLER, Friedrich. Teoria Estruturante do Direto. São Paulo, SP: Revista dos Tribunais, 2008. 
síntese: na teoria estruturante, o sentido de um programa normativo traz o elemento realidade para dentro do conceito normativo.

$\mathrm{Na}$ verdade, a norma jurídica é concebida como um modelo estruturado composto pelo programa da norma (texto) e pelo âmbito da norma (realidade). Como se verá adiante, Konrad Hesse se vale da teoria estruturante da norma para estabelecer os limites da mutação constitucional.

Lenio Streck afasta os dualismos próprios da metafisica e que cindem texto e norma para dizer que o que há entre eles é uma diferença ontológica, de modo que reconhecer que norma e texto são coisas distintas não significa atribuir qualquer sentido ao texto. ${ }^{25}$ Diante disso, alinha-se com Friedrich Müller quando este diz que a norma é sempre produto da interpretação de um texto. Assim, textos não seriam - como não são - meros enunciados linguísticos ${ }^{26} \mathrm{e}$ não subsistem apenas como texto, que não existe isolado da norma. ${ }^{27} \mathrm{O}$ que há entre eles (texto $\mathrm{e}$ norma) é uma diferença ontológica:

Negar que a norma é produto da interpretação do texto e que interpretar é sempre um ato aplicativo (applicatio), implica negar a temporalidade. Os sentidos são temporais. A diferença (que é ontológica) entre texto e norma ocorre na incidência do tempo. Daí a impossibilidade de reprodução de

${ }^{25}$ STRECK, Lenio Luiz. A Diferença Ontológica (entre Texto e Norma) como blindagem contra o Relativismo no Processo Interpretativo: uma análise a partir do Ontological Turn. Revista Brasileira de Estudos Políticos, Vol. 89, 2004, p. 122 e ss.

${ }^{26}$ Streck concorda com SALDANHA, Nelson. Racionalismo jurídico, crise do legalismo e problemática da norma. Anuário dos Cursos de Pós-Graduação em Direito da UFPE, No. 10, 2000, p. 203 e ss., quando este crítica, na transcrição seguinte, os que sustentam que o texto da norma é apenas um enunciado linguístico: "todo texto é um enunciado linguístico, mas nenhum texto é apenas isso: o texto de um poema se distingue de seu 'conteúdo', como ocorre com o de uma prece ou de uma mensagem pessoal. Mas em cada caso o texto está relacionado ao conteúdo: não se procuraria uma mensagem religiosa no texto de um livro de química, nem se buscaria um conteúdo poético no texto de um decreto. Os textos que integram o direito positivo contêm a norma: são textos jurídicos e não contábeis ou litúrgicos. Não se chegaria à norma sem o texto dela, nem com outro que não fosse jurídico. A distinção entre as palavras do texto e o conteúdo normativo não pode levar a uma negação da relação entre ambas as coisas".

${ }^{27}$ STRECK, Lenio Luiz. A Diferença Ontológica (entre Texto e Norma) como blindagem contra o Relativismo no Processo Interpretativo: uma análise a partir do Ontological Turn. Revista Brasileira de Estudos Políticos, Vol. 89, 2004, p. 135. 
sentidos, como se o sentido fosse algo que pudesse ser arrancado dos textos [...]. Os sentidos são atribuíveis, a partir da facticidade em que está inserido o intérprete. [...] A norma será sempre, assim, resultado do processo de atribuição de sentido (Sinngebung) a um texto. Este texto, porém - repita-se - não subsiste com "um ente disperso" no mundo. O texto só é na sua norma. Quando olhamos um texto, o nosso olhar já atribuirá uma determinada norma a esse texto. É nesse sentido que - e isto pode parecer complexo aos olhos do jurista inserido no sentido comum teórico - no plano da filosófica hermenêutica aqui trabalhada, o ser será sempre o ser de um ente. ${ }^{28}$

Sustenta Streck que as palavras não carregam o seu sentido nem o intérprete desaclopa esse sentido do seio das palavras, razão pela qual se faz importante compreender que o que há entre texto e norma é uma diferença, que é ontológica e não metafísica, assim como entre ser e ente ou entre vigência e validade. ${ }^{29}$

\section{Limites à mutação constitucional}

Konrad Hesse pode ser tido como quem mais se preocupou com o tema, a partir mesmo da constatação de que a Teoria da Constituição, construída com base na leitura da Lei Fundamental, pouca atenção deu ao fenômeno da mutação constitucional quando o assunto é lhe estabelecer os limites. ${ }^{30}$ Para ele, diferentemente do que ocorre com os mecanismos formais de mudança (reforma e revisão constitucional), em que os contornos se encontram bem delimitados, igual tratamento não foi dado à mutação constitucional. Apesar de admitida majoritariamente, tendo na "dinâmica interna" e na "historicidade" os vetores que provocam as mudanças informais de uma Constituição, cuja vontade não é imutável, mas cambiante, Hesse lembra que, como não há uma teoria que ofereça respostas quanto aos limites da mutação constitucional,

${ }^{28}$ STRECK, Lenio Luiz. A Diferença Ontológica (entre Texto e Norma) como blindagem contra o Relativismo no Processo Interpretativo: uma análise a partir do Ontological Turn. Revista Brasileira de Estudos Políticos, Vol. 89, 2004, p. 135. ${ }^{29}$ STRECK, Lenio Luiz. A Diferença Ontológica (entre Texto e Norma) como blindagem contra o Relativismo no Processo Interpretativo: uma análise a partir do Ontological Turn. Revista Brasileira de Estudos Políticos, Vol. 89, 2004, p. 150. ${ }^{30}$ HESSE, Konrad. Temas Fundamentais do Direito Constitucional. Trad. Gilmar Ferreira Mendes. São Paulo, SP: Saraiva, 2013, p. 147-171. 
impera a necessidade de enfrentar o assunto. ${ }^{31}$

A partir dos estudos anteriores, Hesse constata que a delimitação do fenômeno da mutação constitucional está diretamente vinculada a um dos problemas da Teoria da Constituição nunca inteiramente resolvido: a relação entre "realidade" e "norma". ${ }^{32}$ Para ele, a estrita separação entre ambas pelas teorias de Laband e Jellinek conduziram, paradoxalmente, não a um fortalecimento da norma, mas à sua capitulação diante dos fatos, sendo em vão a tentativa de solução de Hsü Dau-Lin ao querer aproximar a realidade política (sob a forma de "necessidades vitais do Estado") da Constituição, tornando-a parte integrante da norma constitucional.

É Friedrich Müller quem vai fornecer os elementos para Hesse falando-se aqui em linguagem heideggeriana -, quando este último afirma que:

A mutação constitucional com seus limites só se consegue entender com clareza quando a modificação do conteúdo da norma é compreendida como alteração "no interior" da norma constitucional mesma, não como consequência de desenvolvimentos produzidos fora da normatividade da Constituição, cuja "mutação" em normatividade estatal tampouco se pode explicar satisfatoriamente quando se parte de uma relação de coordenação correlativa entre normalidade e normatividade. Isso militaria em favor de um

${ }^{31}$ HESSE, Konrad. Temas Fundamentais do Direito Constitucional. Trad. Gilmar Ferreira Mendes. São Paulo, SP: Saraiva, 2013, p. 154, esclarece que, ao contrário dos dias de hoje, o tema, no geral, foi extensamente analisado no passado, especificamente durante a vigência da Constituição de 1871, quando se destacaram Laband e Jellinek, embora nenhum deles tenha oferecido uma resposta clara para a questão dos limites, o que não afasta a constatação inequívoca de que a mutação constitucional não sofreu qualquer limitação, tendo sido frustradas quaisquer tentativas nesse sentido. Numa segunda fase, já com Hsü Dau-Lin e Heller, a questão dos limites da mutação constitucional entra na pauta. Mas, como anota Hesse, em relação ao primeiro "o estudo fica sem resultado tangível: em todo caso, não é possível encontrar um limite no sistema constitucional". HESSE, Konrad. Temas Fundamentais do Direito Constitucional. Trad. Gilmar Ferreira Mendes. São Paulo, SP: Saraiva, 2013, p. 160-164. Na Teoria da Constituição de Heller, para Hesse o teórico que mais se aproxima de uma solução, a mutação constitucional encontraria o seu limite na normatividade da Constituição, resposta não satisfatória porquanto não eliminou o caráter genérico do limite, que permanece de difícil precisão.

32 HESSE, Konrad. Temas Fundamentais do Direito Constitucional. Trad. Gilmar Ferreira Mendes. São Paulo, SP: Saraiva, 2013, p. 165.

3 JOURNAL OF INSTITUTIONAL STUDIES 1 (2017) 
ponto de partida semelhante aos de Smend e Hsü Dau-Lin, porém a incorporação da "realidade" à "norma" exige maior clareza e diferenciação. Estas são possíveis a partir dos recentes trabalhos de F. Müller sobre a estrutura das normas constitucionais. ${ }^{33}$

Para o jurista alemão, as normas que conformam o Direito Constitucional não são mandatos abstratos que, alheios à realidade, a ela se contrapõem, caso contrário resultariam em letra morta quando o seu conteúdo não se incorpora à conduta humana mediante aplicação e observância diárias: "Só enquanto o Direito Constitucional é 'realizado' por e nesta conduta alcança a realidade de uma ordem vivida, formadora e conformadora da realidade histórica, capaz, portanto, de cumprir sua função na vida da Comunidade." ${ }^{34}$

No mesmo sentido, afirma que "Do ponto de vista dessa 'realização' do Direito Constitucional, como assinalou F. Müller, a 'norma' não pode ser isolada da 'realidade'; pelo contrário, a 'realidade' em suas circunstâncias (o 'âmbito normativo'), as quais são afetadas pelo mandato da norma (o 'programa normativo'), é parte integrante e constitutiva da norma mesma." 35

Assim, considerando que a norma abarca os dados da realidade afetados pelo "programa normativo" como parte material integrante da norma, o "âmbito normativo" e suas modificações levam a uma alteração do conteúdo da norma, mas somente quando o fato que se modificou pertencer ao âmbito normativo é que será possível uma mudança na norma. É possível que, diz Hesse, estejamos diante de um ponto de partida que, se for correto, permitirá uma resposta correta para a questão dos limites da mutação constitucional, pois:

Se as modificações da realidade social só devem considerar-se relevantes para o conteúdo da norma enquanto fazem parte do âmbito normativo, se o "programa normativo" resulta determinante a esse respeito e se para este último resulta fundamental o texto da norma, então o conteúdo da norma constitucional só poderá modificar-se no interior do marco traçado pelo texto. [...] Onde termina a possibilidade de uma compreensão lógica do texto da

${ }^{33}$ HESSE, Konrad. Temas Fundamentais do Direito Constitucional. Trad. Gilmar Ferreira Mendes. São Paulo, SP: Saraiva, 2013, p. 166.

${ }^{34}$ HESSE, Konrad. Temas Fundamentais do Direito Constitucional. Trad. Gilmar Ferreira Mendes. São Paulo, SP: Saraiva, 2013, p. 166.

${ }^{35}$ HESSE, Konrad. Temas Fundamentais do Direito Constitucional. Trad. Gilmar Ferreira Mendes. São Paulo, SP: Saraiva, 2013, p. 166-167 
norma ou onde uma determinada mutação constitucional apareceria em clara contradição com o texto da norma, assim encerram-se as possibilidades de interpretação da norma e, com isso, também as possibilidades de uma mutação constitucional [...]. Portanto, o texto da Constituição se erige em limite absoluto de uma mutação não só do ponto de vista da relação entre "Direito" e "realidade constitucional", a qual encontra expressão na estrutura da norma constitucional, como também do ponto de vista das funções da Constituição. ${ }^{36}$

Em síntese: a partir das contribuições de Müller, Hesse diz que a mutação constitucional está restrita à hipótese de mudança de conteúdo da norma constitucional à qual se atribui um significado diferente, compatível com a elasticidade (condição de possibilidade) interpretativa de seu texto, que permanece inalterado, ocorrendo o fenômeno no interior da norma e dentro dos limites (marcos) traçados pelas diferentes possibilidades de interpretação do texto constitucional. Sendo mais claro: as mutações constitucionais decorrem das alterações ocorridas no âmbito normativo desde que elas (no elemento realidade) possam ser compatíveis/conciliadas com as diferentes e possíveis compreensões do texto da norma (capacidade de distender, dado que a elasticidade é que irá estabelecer os limites e as condições de possibilidades da mutação constitucional). Não sendo isso possível, não há que se falar em mutação constitucional.

A propósito de elasticidade, Adriano Pedra, alinhando-se a essa forma de pensar, deixa claro que, por força da própria natureza da mutação constitucional informal, o texto se configura como um teto hermenêutico. Não exatamente a letra do texto, mas a elasticidade que ele pode suportar. Em sintonia com Hesse, afirma que o texto normativo constitui o ponto de partida da atividade interpretativa e também lhe servirá de parâmetro, dizendo ainda que o significado normativo é aquilo que este suscita na mente do intérprete. Disso resulta que "quando se afirma que o texto possui uma elasticidade de interpretação o que se quer dizer é que não se pode extrair do texto aquilo que ele não suscita na mente do intérprete." 37

Por tais razões, não há como concordar com Bulos quando afirma que as mudanças informais não encontram qualquer limite em seu exercício e que, se há um limite, este "seria a consciência do intérprete de não

${ }^{36}$ HESSE, Konrad. Temas Fundamentais do Direito Constitucional. Trad. Gilmar Ferreira Mendes. São Paulo, SP: Saraiva, 2013, p. 168-169.

${ }^{77}$ PEDRA, Adriano Sant'Ana. Teoria da Mutação Constitucional: limites e possibilidades das Mudanças Informais da Constituição a partir da Teoria da Concretização. 331 f. 2009. Tese (Doutorado em Direito), Programa de Pós-Graduação, Pontifícia Universidade Católica de São Paulo, São Paulo, SP, 2009, p. 203. 
extrapolar a forma plasmada na letra dos preceptivos supremos do Estado, através de interpretação deformadora dos princípios fundamentais que embasam o Documento Maior." 38 Numa palavra: a limitação, se existir, seria de natureza subjetiva ou psicológica, dando a entender o autor que aposta no protagonismo judicial.

De modo diferente, Hesse sustenta que, a se considerar o texto como limite, se terá conseguido uma garantia contra as mutações constitucionais ilimitadas, ainda que de caráter não absoluto, eis que não restringe a capacidade de adaptação da Constituição a tal ponto que, no ápice, lhe impeça de assimilar a mudança histórica, preservando-lhe, assim, sua continuidade. No caso, a alternativa às dificuldades derivadas da submissão aos limites estabelecidos seria impor uma reforma à Constituição que tenha limites e contornos bem definidos, de sorte a contribuir "para uma solução que sirva à sua clareza e intensifique a sua força normativa". Em síntese: uma vez esgotadas as possibilidades de mutação constitucional tendo como régua a elasticidade do texto, para incorporar o tempo do direito é de se pensar em reforma ou revisão constitucional, dado que o texto foi tensionado ao máximo e insistir na ideia pode resultar, simplesmente, em rompimento. Aliás, é nesse sentido a conclusão do mestre alemão: "Tudo o que se situe mais além das possibilidades já não será mutação constitucional, e sim quebra constitucional, ou anulação." 39

\section{A MUTAÇÃO CONSTITUCIONAL E OS PARADIGMAS DA FILOSOFIA}

A Filosofia ocidental, em seus mais de dois milênios de desenvolvimento, experimentou pelo menos três paradigmas da linguagem, dos quais dois deles são vinculados diretamente ao esquema sujeito-objeto, também denominado paradigma representacional. Em ambos, a aposta é ora no sujeito, ora no objeto.

Antes de tratar dos dois primeiros paradigmas, atente-se para as seguintes expressões:

1) “Há uma verdade absoluta, que independe do conhecimento

${ }^{38}$ BULOS, Uadi Lammêgo. Mutação constitucional. São Paulo, SP: Saraiva, 1997, p. 91.

${ }^{39}$ HESSE, Konrad. Temas Fundamentais do Direito Constitucional. Trad. Gilmar Ferreira Mendes. São Paulo, SP: Saraiva, 2013, p. 170. 
do sujeito".

2) "Há um sujeito que conhece o objeto".

O que há de comum nessas duas expressões é que ambas representam a síntese do paradigma de duas metafísicas, a clássica (também chamada aristotélico-tomista) e a moderna (filosofia da consciência) e se sustentam no mesmo esquema sujeito-objeto. Nelas imperam uma ação, que pode ser denominada de assujeitamento, no interior da qual a linguagem funciona apenas como uma terceira coisa, que se interpõe entre o sujeito (que conhece) e o objeto (que é conhecido).

A primeira teve origem na Grécia antiga, atravessou o Medievo quando adotada por Tomás de Aquino, virou filosofia aristotélicotomista - e chegou às portas da Idade Moderna, restando substituída então, em uma verdadeira revolução copernicana, pela filosofia da consciência, de caráter subjetivista, inaugurada por Descartes e seu cogito, ergo sum. Conforme sublinha Fernando Vieira Luiz, a metafísica clássica refere-se a um período em que a filosofia da linguagem possui um perfil notadamente objetivista, eis que o significado é concebido como algo que existe independentemente da própria linguagem ou do sujeito, o que daria razão para a expressão há uma verdade absoluta, que independe do conhecimento do sujeito. ${ }^{40}$ Nesse paradigma, o sujeito, na relação sujeitoobjeto, é assujeitado pelo objeto. Em outras palavras, para as posturas objetivistas, a linguagem funciona somente como meio de expressão, mero instrumento de designação de um objeto ideal que, em si, já possui uma essência. A linguagem, nesse cenário, apenas ajudaria na busca dessa essência.

Esse paradigma objetivista, seja da filosofia aristotélico-tomista ou da metafísica clássica, vai ser rompido com o cogito, ergo sum, de Descartes, e as investigações filosóficas de Kant. A linguagem continuará sem função substantiva, a exercer um papel instrumental, mas o paradigma essencialista será quebrado, dado que entra em cena o subjetivismo da metafísica moderna, cujo resultado é o seguinte: o sujeito, até então assujeitado pelo objeto, passa a ser um sujeito assujeitador, senhor dos sentidos e dos significados, legitimando então a expressão há um sujeito que conhece o objeto. Enfim, enquanto na metafísica clássica o fundamentum absolutum inconcussum veritatis ${ }^{41}$ pode ser encontrado na "essência" do

${ }^{40}$ LUIZ, Fernando Vieira. Teoria da Decisão Judicial: dos paradigmas de Ricardo Lorenzetti à resposta adequada à Constituição de Lenio Streck. Porto Alegre, RS: Livraria do Advogado, 2013, p. 22.

${ }^{41}$ Fundamento último no qual se funda o conhecimento, próprio do pensamento filosófico metafísico. 
objeto, na metafísica moderna ele estará na "consciência" do sujeito, em si mesmo, pensante.

Tudo isso será superado com o movimento filosófico caracterizado pela invasão da filosofia pela linguagem, que se tornou conhecido como reviravolta linguístico-pragmática ou viragem linguístico-ontológica (linguistic turn), por força do que a linguagem, de terceira coisa que se interpõe entre um sujeito e um objeto, passa a ocupar uma posição cimeira. Com essa ruptura, também considerada uma revolução copernicana por abalar o pensamento dominante, inaugura-se o terceiro paradigma da filosofia. Sai de cena o paradigma da filosofia da consciência, que dá lugar ao da filosofia da linguagem, em cujo interior a linguagem não está mais relegada a uma posição de terceira coisa entre o sujeito e o objeto, pois tomada como ponta de lança e condição de possibilidade não só para fins de interpretação dos textos, mas também da própria condição e existência humanas. Supera-se, enfim, o esquema sujeito-objeto e, no lugar do sujeito solipsista, aparece a intersubjetividade.

A invasão da filosofia pela linguagem produziu reflexos nos mais variados ramos de conhecimento e não se vislumbra qualquer argumento racional que justifique a ideia de que o direito tenha ficado à margem desses influxos. Ocorre que, como se verá a seguir, o direito, aqui representado pela dogmática jurídica, pelo senso comum teórico e pelas decisões dos tribunais, tem-se mostrado refratário à reviravolta da linguagem e resistente ao novo paradigma filosófico da intersubjetividade, no qual a linguagem ocupa uma posição de centralidade.

Como subproduto dessa resistência, o fenômeno da mutação constitucional informal se insere como um de seus maiores representantes, sobretudo se exercida sem limites, dado que, como manifestação, oscila entre a metafísica clássica (aristotélico-tomista) e a moderna (filosofia da consciência), pendendo muito mais para a última.

\section{A ausência de limites à mutação constitucional como submissão à Filosofia da Consciência}

O constitucionalismo democrático, com seu modelo garantidor dos direitos fundamentais do ser humano, é uma prova indiscutível da validade e atualidade de uma antiga sabedoria popular: não há um mal que não traga um bem. Sim, porque ninguém há de discordar que o constitucionalismo democrático foi um dos maiores resultados 
transmitidos pelas lições aprendidas com a Segunda Guerra Mundial, sendo também correto afirmar que a conquista do Estado de Direito provocou um deslocamento do polo de tensão (anteriormente distribuído entre o Executivo e o Legislativo) para o Judiciário, que passa cada vez mais a ser chamado para decidir questões de políticas públicas, dado que as Constituições modernas se revestem "com a roupagem de précompromisso, no sentido de que operam como restrições que os próprios atores políticos estabelecem para si e para as futuras gerações, na intenção de garantir um governo que esteja sob o Direito, e não sobre ele." ${ }^{42}$ Esse deslocamento vem acompanhado (ou vai gerar) um problema histórico nem sempre bem resolvido: o dos limites da interpretação judicial.

Lima, Streck e Oliveira sustentam que o Estado Democrático de Direito deve ser compreendido no contexto da ruptura paradigmática ocorrida no campo da filosofia: a superação do esquema sujeito-objeto responsável pela derrota das posturas subjetivistas ou solipsistas. ${ }^{43}$ Assim, não pode o direito ficar à margem da viragem ocorrida, muito menos naquilo que é considerado uma das suas questões centrais e nuclear forma de concretização: a interpretação judicial ou, numa palavra, a decisão judicial, disso resultando que " a derrocada do esquema sujeito-objeto [..] tem repercussão no novo modelo de Estado e de direito exsurgido a partir do segundo pós-guerra, de sorte que o sujeito solipsista (Selbstsüchiger) dá lugar à intersubjetividade." 44

Entretanto, para estes mesmos autores, a reviravolta linguística também foi mal compreendida pela tese da mutação constitucional. Ocorre que o direito, a partir do novo paradigma, não pode ser entendido como um "espaço de livre atribuição de sentido", questão que assume maior relevância quando o objeto de mutação é o texto constitucional.

${ }^{42}$ LEMOS, Tayara Talita, et. al.. Mutação Constitucional e Democracia: uma (des)construção hermenêutica do problema da intervenção do Senado em sede de Controle Difuso de Constitucionalidade. Anais do IX Simpósio Nacional de Direito Constitucional da ABDConst. Curitiba, PR; ABDConst, 2011. Disponível em: $<$ http://www.abdconst.com.br/revista3/franca.pdf $>$. Acesso em: 10 de agosto de 2017, p. 360-361.

${ }^{43}$ LIMA, Martônio Mont'Alverne Barreto; STRECK, Lenio Luiz; CATTONI DE OLIVEIRA, Marcelo Andrade. A Nova Perspectiva do Supremo Tribunal Federal sobre o Controle Difuso: Mutação Constitucional e Limites da Legitimidade da Jurisdição Constitucional. Argumenta Journal Law, No. 7, 2007, p. 17.

${ }^{44}$ LIMA, Martônio Mont'Alverne Barreto; STRECK, Lenio Luiz; CATTONI DE OLIVEIRA, Marcelo Andrade. A Nova Perspectiva do Supremo Tribunal Federal sobre o Controle Difuso: Mutação Constitucional e Limites da Legitimidade da Jurisdição Constitucional. Argumenta Journal Law, No. 7, 2007, p. 17. 
Ora, os citados autores dizem que "em determinadas situações, mutação constitucional pode significar, equivocadamente, 'a substituição do Poder Constituinte pelo Poder Judiciário', soçobrando, com isso, a democracia." 45

Ao mesmo entendimento alinha-se Fernando Vieira Luiz, para quem o exercício da jurisdição no Brasil se oscila entre posturas objetivistas e subjetivistas, dado que não houve no e para o Direito a recepção do giro linguístico, embora sem qualquer razão lógica para essa blindagem:

As teorias acerca da decisão judicial tradicionalmente trabalhadas voltam-se ao objetivismo e ao subjetivismo na interpretação. A primeira considera que a lei traz em si a norma (desprezando a diferença ontológica entre ambas) e que, por isso, a interpretação judicial é objetivamente controlada pelas regras, as quais levam a uma correta determinação do significado do texto, como se a verdade estivesse "nas coisas", retomando a metafísica clássica. A segunda vê a interpretação judicial como sendo subjetivamente determinada pelas preferências valorativas pessoais do intérprete - como seu senso de justiça - o qual, em última análise, dá ao texto o significado que lhe aprouver - como se houvesse um 'grau zero' de significância (na expressão de Streck) -, utilizandose, também, como pano de fundo, uma visão metafísica, calcada na filosofia da consciência. Assim, a aplicação do Direito é realizada por um sujeito solipsista, proprietário dos significados, que, julgando conforme sua consciência, acredita - de forma alienada - estar decidindo corretamente (com justiça) as questões que lhe são postas. ${ }^{46}$

Para este autor, "o sujeito solipsista da modernidade - cujas bases são as formulações de Descartes e Kant - é o protótipo do juiz atual. O solipsismo ocorre aberta ou veladamente, de várias formas, possuindo, em comum, o fato de relegar a decisão à consciência ou à conviç̧ão pessoal do julgador." 47

E como se manifesta esse solipsismo? Streck elenca as suas diversas

${ }^{45}$ LIMA, Martônio Mont'Alverne Barreto; STRECK, Lenio Luiz; CATTONI DE

OLIVEIRA, Marcelo Andrade. A Nova Perspectiva do Supremo Tribunal Federal sobre o Controle Difuso: Mutação Constitucional e Limites da Legitimidade da Jurisdição Constitucional. Argumenta Journal Law, No. 7, 2007, p. 19 (grifos no original).

${ }^{46}$ LUIZ, Fernando Vieira. Teoria da Decisão Judicial: dos paradigmas de Ricardo Lorenzetti à resposta adequada à Constituição de Lenio Streck. Porto Alegre, RS: Livraria do Advogado, 2013, p. 35.

${ }^{47}$ LUIZ, Fernando Vieira. Teoria da Decisão Judicial: dos paradigmas de Ricardo Lorenzetti à resposta adequada à Constituição de Lenio Streck. Porto Alegre, RS: Livraria do Advogado, 2013, p. 54.

3 JOURNAL OF INSTITUTIONAL STUDIES 1 (2017) 
formas de manifestação, fruto de uma aposta na consciência ou na convicção pessoal como balizadores do juiz no ato de decidir. Ei-las:

a) interpretação como ato de vontade do juiz ou no adágio 'sentença com sentire'; b) interpretação como fruto da subjetividade judicial; $c$ ) interpretação como produto da consciência do julgador; $d$ ) crença de que o juiz deve fazer a 'ponderação de valores' a partir de seus 'valores'; e) razoabilidade e/ou proporcionalidade como ato voluntário do julgador; f) crença de que 'os casos difíceis se resolvem discricionariamente'; $g$ ) cisão estrutural entre regras e princípios, em que estes proporciona(ria)m uma 'abertura de sentido' que deverá ser preenchida e/ou produzida pelo intérprete.” ${ }^{48}$

Perceba-se que a mutação constitucional, quando exercida sem limites, como se ilustrará adiante, assume as vestes, pelo menos, das três primeiras manifestações solipisistas descritas na passagem colacionada acima, com destaque para a referenciada na letra $c$ (interpretação como produto da consciência do julgador). A propósito, a possibilidade da mutação constitucional se constituir em um produto de uma postura subjetiva do julgador é reconhecida expressamente por Hesse, quando admite que ela, exercida dentro dos limites do texto, "necessita ainda ser desenvolvida em busca de parâmetros concretos, comprováveis e manejáveis na prática $[. .$.$] ", embora "nada disso altere o fato de que, ao$ menos desse modo, a discricionariedade na invocação da presença de uma mutação constitucional se reduz essencialmente." 49

Registre-se que, em matéria de mutação constitucional, há no Supremo Tribunal Federal a prática de se atribuir sentidos ao texto constitucional de forma casuísta ou de acordo com a consciência de cada ministro, o que resulta em contradições argumentativas e perda de coerência interna do Colegiado. De fato, Flávio Pedron, ao analisar vários casos de mutações constitucionais operadas no STF, chegou à conclusão de que se percebe uma total divergência da compreensão de mutação constitucional, destacando que a expressão ganhou, naquela Corte, sentido meramente retórico, "já que os ministros não conseguem sequer atingir uma coerência interna". ${ }^{50}$ Para o autor, é comum a utilização, de

${ }^{48}$ STRECK, Lenio Luiz. O que é isto - decido conforme minha consciência? $4^{\mathrm{a}}$ ed. Porto Alegre, RS: Livraria do Advogado, 2013, p. 33 (grifos no original).

${ }^{49}$ HESSE, Konrad. Temas Fundamentais do Direito Constitucional. Trad. Gilmar Ferreira Mendes. São Paulo, SP: Saraiva, 2013, p. 168 (grifos nossos).

${ }^{50}$ PEDRON, Flávio Barbosa Quinad. A Mutação Constitucional na crise do Positivismo Jurídico: história e crítica do conceito no marco da Teoria do Direito como Integridade. 228 f. 2011. Tese (Doutorado em Direito), Programa de Pós- 
uma decisão para outra, do mesmo termo com sentidos totalmente diferentes, o que revela a despreocupação de estabelecer uma concordância entre eles mesmos em torno do significado do tema. ${ }^{51}$

Embora tenha objeto de estudo diverso do adotado na presente pesquisa, Virgílio Afonso da Silva, ao examinar o papel do relator nos julgamentos de processos do STF, com base em entrevistas realizadas pelo autor para o referido estudo, conclui que a própria falta de coerência interna do Colegiado em algumas decisões pode estar associado ao fato de ter o relator um "voto qualquer" no acórdão final, pois o seu voto sequer deve ser internamente divulgado aos pares, para ciência, antes da sessão de julgamento. Esta simples mudança, tida como positiva pela maioria dos ministros entrevistados, "provavelmente, aproximaria o relator no Supremo Tribunal Federal da imagem que se costuma ter dele, isto é, a de um ministro que tem um papel preponderante no desenvolvimento da deliberação e do processo decisório." 52

Já a seu turno, vale referir estudo de Renan Carvalho, intitulado Qual é o conceito de mutação constitucional para os ministros do STF?, em que diz, em suas conclusões, que a resposta é indefinida, uma vez que, no que se refere os Ministros Eros Grau, Gilmar Mendes e Carlos Ayres de Brito, estes utilizaram o instituto da mutação constitucional mais de uma vez em seus votos e em todas a aplicação foi diferente. Diz ainda que o mais curioso é que, em dado momento, um ministro critica a utilização do instituto de determinada maneira e em voto seguinte aplica a mutação constitucional exatamente da forma que criticara, citando como exemplos Eros Grau (Recl. 4.335-5/AC e MS 26.603/DF) e Gilmar Mendes (Recl.

Graduação da Faculdade de Direito, Universidade Federal de Minas Gerais, Belo Horizonte, MG, 2011, p. 64.

51 "Ao que se mostra, quando um ministro pretende dizer que sua interpretação é revolucionária, ele diz que está fazendo uma mutação constitucional. Ora, esse não é o propósito do conceito em estudo, de modo que essa total falta de rigor pelos membros do Tribunal acaba por denotar, inclusive, uma despreocupação técnico-científica com o Direito Constitucional brasileiro." PEDRON, Flávio Barbosa Quinad. A Mutação Constitucional na crise do Positivismo Jurídico: história e crítica do conceito no marco da Teoria do Direito como Integridade. 228 f. 2011. Tese (Doutorado em Direito), Programa de Pós-Graduação da Faculdade de Direito, Universidade Federal de Minas Gerais, Belo Horizonte, MG, 2011, p. 164.

52 SILVA, Vírgilio Afono da. "Um Voto Qualquer?" O papel do Ministro Relator na Deliberação do Supremo Tribunal Federal. Revista de Estudos Institucionais, Vol. 1, 1, 2015, p. 199. 
4.335-5/AC e ADI $3.838 \mathrm{MC} / \mathrm{DF}) .{ }^{53}$

Do mesmo modo, Barata registra que no STF a expressão mutação constitucional já foi utilizada de diversas maneiras, tanto no sentido de "alteração de situação ou pressuposto fático que altere a compreensão de determinado texto constitucional" 54 , atitude que considera adequada, como de fato é, de acordo com a doutrina especializada, quanto nos sentidos inadequados de "alteração formal da Constituição (emendamento)" 55 e "mudança de interpretação". ${ }^{56}$ Diz o autor que, em pelo menos seis oportunidades, o STF se utilizou da expressão mutação constitucional para se referir à alteração formal da Constituição por meio de emendas, e observa que há contradição inegável em afirmações comuns do tipo "a mudança na jurisprudência do Supremo surgiu por mutação constitucional", sendo a expressão usada apenas para justificar uma mudança de pensamento ou de opinião do tribunal sobre determinado assunto. ${ }^{57}$

${ }^{53}$ CARVALHO, Renan Flumian de. Qual é o conceito de Mutação Constitucional para os Ministros do STF? 69 f. 2009. Monografia (Bacharelado em Direito), Escola de Formação, Sociedade Brasileira de Direito Público, São Paulo, SP, 2009, p. 46.

Disponível em:

<http://www.sbdp.org.br/arquivos/monografia/138 Monografia\%20Renan.pdf $>$. Acesso em: 10 de agosto de 2017.

${ }^{54}$ BARATA, Rodrigo Sarmento. A Mutação Constitucional e o STF: sua utilização e algumas perspectivas. In: Adriana Vojvodic; Henrique Motta Pinto; Paula Gorzoni; Rodrigo Pagani de Souza (Orgs.). Jurisdição Constitucional no Brasil. São Paulo, SP: Malheiros, 2012, p. 392.

${ }^{55}$ A ocorrência, segundo o autor, ocorreu nos seguintes processos: AI 611.481-MG; RE 488.165-PR; Recl. 7.336-SP; RE 466.215-RS; RE 517.766-RS e AI 618.763-RS.

56 Verificadas, segundo o autor, nos seguintes casos: RE/AgR 450.504-5-MG; HC/QO 86.009-5DF; RE/ED/EDv 174.161-9/DF; RE/EDv 166.791-5-DF; HC 92.297-MG; Recl. 3.801-GO; MS 26.602-DF; MS 26.603-DF e MS 26.604-DF.

57 “A utilização da mutação constitucional como mera alteração de interpretação foi reconhecida em nove situações, restando em todas muito clara a intenção dos ministros de justificar uma mudança de posicionamento em comparação a decisões anteriores da Corte; a expressão "mutação constitucional" constitucional é posta como superação de jurisprudência anterior, mas por razões que nada têm a ver com alterações no contexto fático, tais como mudança da composição da Corte, reconhecimento de interpretação equivocada ou simples mudança de opinião." BARATA, Rodrigo Sarmento. A Mutação Constitucional e o STF: sua utilização e algumas perspectivas. In: Adriana Vojvodic; Henrique Motta Pinto; Paula Gorzoni; 
As pesquisas realizadas pelos autores citados demonstram a prevalência, no exercício da jurisdição, em especial no STF, da filosofia da consciência, "consubstanciada num julgador solipsista que, como proprietário dos significantes, molda as leis, e mesmo a Constituição, apenas aos ditames de sua consciência." 58 Exemplo latente disso é o voto do Ministro Eros Grau na Recl. 4.335-5/AC, que em determinado trecho deixa claro que, por força do compromisso que assumiu de guardar a Constituição, é livre para decidir independentemente do que pensa acerca do assunto a doutrina. A propósito, Pedron lembra que a Reclamação n. 4.335-5/AC é o melhor cenário para se pensar a compreensão do significado de mutação constitucional e seus limites e de se demonstrar a fragilidade como esse significado vem sendo construído, a julgar pela interpretação do STF. ${ }^{59}$

\section{Superando os limites da mutação constitucional: evolução normativa ou patologia constitucional?}

Os teóricos da mutação constitucional são amplamente favoráveis a dizer (cite-se, na sequência, por todos, Hesse) que a mutação constitucional "consiste em modificar o conteúdo das normas constitucionais mantendo intacto o texto literal." 60

Nesse sentido, segundo síntese feita por Hesse, Laband identificou possíveis mudanças importantes da situação constitucional que não alcançaram expressão na Constituição; já Jellinek entendeu que, diferentemente do que se dá na reforma constitucional, cujas mudanças se produzem de forma consciente e reguladas, na mutação constitucional dá-se "aquela modificação que permite deixar estes textos formalmente

Rodrigo Pagani de Souza (Orgs.). Jurisdição Constitucional no Brasil. São Paulo, SP: Malheiros, 2012, p. 393.

${ }^{58}$ LUIZ, Fernando Vieira. Teoria da Decisão Judicial: dos paradigmas de Ricardo Lorenzetti à resposta adequada à Constituição de Lenio Streck. Porto Alegre, RS: Livraria do Advogado, 2013, p. 59.

${ }^{59}$ PEDRON, Flávio Barbosa Quinad. A Mutação Constitucional na crise do Positivismo Jurídico: história e crítica do conceito no marco da Teoria do Direito como Integridade. 228 f. 2011. Tese (Doutorado em Direito), Programa de PósGraduação da Faculdade de Direito, Universidade Federal de Minas Gerais, Belo Horizonte, MG, 2011, p. 65.

${ }^{60}$ HESSE, Konrad. Temas Fundamentais do Direito Constitucional. Trad. Gilmar Ferreira Mendes. São Paulo, SP: Saraiva, 2013, p. 14. 
intactos e que é provocada por fatos que não têm que ser acompanhados de algum propósito ou consciência de tal modificação". ${ }^{61}$ Para Kelsen, também citado por Hesse, a mutação constitucional consiste na modificação lenta e imperceptível da aplicação das normas constitucionais, sem que as palavras sofram alteração no texto, atribuindo-se àquelas um sentido distinto do original, ou se configura numa prática em contradição com o texto e com qualquer sentido possível da Constituição. Por fim, Hesse diz que, para Hsü Dau-Lin, "a mutação constitucional não é quebra da Constituição nem simples regra convencional, mas algo admitido no Direito Constitucional comparado e, portanto, Direito, apesar de não coincidir com o texto da norma." 62

Vê-se, assim, que todos os conceitos, como salienta Hesse, consideram que o fenômeno da mutação deve limitar-se ao conteúdo das normas constitucionais, permanecendo inalterado o texto. ${ }^{63}$ Ocorre que, ao propor a substituição da atual redação do art. 52, X, da Constituição de 1988 , por uma interpretação diversa daquela literal, verifica-se que o voto proferido pelo então Ministro Eros Grau na Recl. 4.335-5/AC contraria o entendimento geral de mutação constitucional, desde Laband a Hesse, passando por Jellinek, Kelsen e Dau-Lin. Todos, sem exceção, sustentam que o fenômeno da mutação constitucional preserva o texto da norma, que é alvo da mudança, apenas, de sentido ou significado.

$\mathrm{O}$ voto em referência, tomado aqui apenas ilustrativamente, não guarda sintonia com o pensamento dos principais teóricos da mutação da Constituição, nem mesmo com o do jurista Eros Grau, que entendia, em uma de suas obras capitais, não haver espaço para a discricionariedade, de modo que o fato, de um lado, do intérprete, sobretudo o juiz, não se vincular à vontade da lei ou do legislador, "associado à necessidade de se buscar no presente as circunstâncias que animam, conferindo-lhes vida, os princípios, de outro, não importam, no entanto, possa ele atuar discricionariamente." 64 Destaca, ainda, a impossibilidade de o juiz criar ou recriar livremente o direito, dado que está sempre vinculado pelas normas jurídicas, especialmente pelos princípios.

Sucede que, como anota Pedron, na Recl. 4.335-5/AC, "merece

${ }^{61}$ HESSE, Konrad. Temas Fundamentais do Direito Constitucional. Trad. Gilmar Ferreira Mendes. São Paulo, SP: Saraiva, 2013, p. 151-152.

62 HESSE, Konrad. Temas Fundamentais do Direito Constitucional. Trad. Gilmar Ferreira Mendes. São Paulo, SP: Saraiva, 2013, p. 160.

${ }^{63}$ HESSE, Konrad. Temas Fundamentais do Direito Constitucional. Trad. Gilmar Ferreira Mendes. São Paulo, SP: Saraiva, 2013, p. 153.

${ }^{64}$ GRAU, Eros Roberto. A Ordem Econômica na Constituição de 1988. São Paulo, SP: Malheiros, 1998, p. 184 (grifos nossos). 
destaque a leitura nitidamente ímpar que o Min. Eros Grau faz da figura da mutação constitucional." ${ }^{65}$ Depois de, no voto, indagar "até que ponto o intérprete pode caminhar, para além do texto que o vincula", e de afirmar "ainda que operem o que chamamos de mudança de jurisprudência, os intérpretes autênticos não estão livres para modificálo, o texto normativo, à vontade, reescrevendo-o a seu bel-prazer", "o intérprete inscreve-se na tradição do texto", "há de construir a norma respeitando a coerência interna do texto" e "a mutação constitucional é transformação de sentido do enunciado da Constituição sem que o próprio texto seja alterado em sua redação, vale dizer, na sua dimensão constitucional textual", o ministro, com o que em resposta ao que indagara, assinala que o intérprete, como que agindo como o sujeito da modernidade, de forma assujeitadora (e aqui ele invoca o relator da Recl. 4.335-5/AC, o ministro Gilmar Mendes), pode marchar "até o ponto de propor a substituição de um texto normativo por outro", justificando que "por isso aqui mencionamos a mutação constitucional". Concluindo o raciocínio, propõe uma nova redação para o inciso $X$ do art. 52 da Constituição Federal:

Há, então, mais do que interpretação, esta concebida como processo que opera transformação de texto em norma. Na mutação constitucional caminhamos não de um texto a uma norma, porém de um texto a outro texto, que substitui o primeiro. Daí que a mutação constitucional não se dá simplesmente pelo fato de um intérprete extrair de um mesmo texto norma diversa da produzida por um outro intérprete. [...] Na mutação constitucional há mais. Nela não apenas a norma é outra, mas o próprio enunciado normativo é alterado. $\mathrm{O}$ exemplo que no caso se colhe é extremamente rico. Aqui passamos em verdade de um texto [compete privativamente ao Senado Federal suspender a execução, no todo ou em parte, de lei declarada inconstitucional por decisão definitiva do Supremo Tribunal Federal] a outro texto [compete privativamente ao Senado Federal dar publicidade à suspensão da execução operada pelo Supremo Tribunal Federal, no todo ou em parte, por decisão definitiva do Supremo]. ${ }^{66}$

Destaque-se ainda que, para o Ministro Eros Grau, no mesmo voto,

65 PEDRON, Flávio Barbosa Quinad. A Mutação Constitucional na crise do Positivismo Jurídico: história e crítica do conceito no marco da Teoria do Direito como Integridade. 228 f. 2011. Tese (Doutorado em Direito), Programa de PósGraduação da Faculdade de Direito, Universidade Federal de Minas Gerais, Belo Horizonte, MG, 2011, p. 29.

${ }^{66}$ Reclamação n. 4.335-5/AC, p. 9-10 do voto-vista do ministro Eros Grau. 
"pouco importa a circunstância de resultar estranha e peculiar, no novo texto, a competência conferida ao Senado Federal", restrita ao dever de dar publicidade à decisão do STF, dado que essa peculiaridade decorre do fato de cogitar-se de uma situação de mutação constitucional. Numa só palavra: o Ministro Eros Grau equipara, em termos de efeitos, a mutação constitucional a uma mudança formal da Constituição (Emenda).

Todavia, há ainda uma outra questão que merece ser referida neste voto. Após afirmar que, como a atual redação do art. 52, X, é obsoleta, seria melhor compreender que a competência do Senado Federal deverá ser restrita a dar publicidade às decisões do Supremo em sede de controle difuso, o Ministro Eros Grau se diz sabedor de que a doutrina se insurgirá contra seu entendimento, razão pela qual antecipa sua defesa:

Sucede que estamos aqui não para caminhar seguindo os passos da doutrina, mas para produzir o direito e reproduzir o ordenamento. Ela nos acompanhará, a doutrina. Prontamente ou com alguma relutância. Mas sempre nos acompanhará, se nos mantivermos fiéis ao compromisso de que se nutre a nossa legitimidade, o compromisso de guardarmos a Constituição. $\mathrm{O}$ discurso da doutrina [= discurso sobre o direito] é caudatário do nosso discurso, o discurso do direito. Ela nos seguirá; não o inverso. ${ }^{67}$

Trata-se, a toda evidência, de posicionamento diametralmente oposto ao do outrora doutrinador, que entendia que o intérprete não podia criar nem recriar o direito e, muito menos, agir de forma discricionária.

Como sustenta Carvalho, o conceito e o limite de mutação constitucional no caso em exame colidem com a Constituição Federal, dado que a única forma de mudar o seu texto é por meio de reforma constitucional e somente o Poder Legislativo a tanto se encontra autorizado, devendo, ainda, observar o procedimento específico, pois "o juiz não é nem competente e nem pode se socorrer do procedimento adequado para prover à alteração constitucional. Destarte, uma alteração do texto constitucional pela via interpretativa jurisdicional (exatamente como o que Eros Grau propôs) atenta contra a Constituição." 68

${ }^{67}$ Reclamação n. 4.335-5/AC, p. 14 do voto-vista do ministro Eros Grau.

${ }^{68}$ CARVALHO, Renan Flumian de. Qual é o conceito de Mutação Constitucional para os Ministros do STF? 69 f. 2009. Monografia (Bacharelado em Direito), Escola de Formação, Sociedade Brasileira de Direito Público, São Paulo, SP, 2009, p. 25.

Disponível em:

$<$ http://www.sbdp.org.br/arquivos/monografia/138 Monografia\%20Renan.pdf $>$. Acesso em: 10 de agosto de 2017.

3 JOURNAL OF INSTITUTIONAL STUDIES 1 (2017) 
A propósito, pode dizer-se, com Müller, que o voto em exame equipara o art. 52, X, da Constituição de 1988, a um dispositivo qualquer do Código de Hamurabi, a uma norma "pura" qualquer, sem conteúdo, sem realidade, sem âmbito normativo. Friedrich Müller diz que "norma pura" é aquela que não possui uma normatividade concreta, eis que não possui nem conteúdo nem determinação material. ${ }^{69}$ Segue ainda afirmando que: "Ela constitui apenas texto de norma. No sentido do conceito normativo aqui desenvolvido, entretanto, não constitui nem mesmo isso, mas apenas um texto que dever ser visto como forma linguística de uma norma." 70

Nessa linha de raciocínio, diz o autor que uma disposição legal do Código de Hamurabi é um típico exemplo de "norma pura", dado que o seu âmbito normativo se perdeu, não se tratando mais de um texto de norma, mas de um mero texto linguístico. Nesse sentido, há uma percepção geral no meio jurídico de que "o positivismo da ciência jurídica, justamente em sua escalada rumo ao normologismo, hoje em dia concebe disposições válidas do ordenamento jurídico atual como textos sem âmbito normativo, como normas puras, libertas de qualquer peso terreno." 71

É o que parece ter ocorrido no voto em pauta que, fazendo tábula rasa do texto normativo contido no art. 52, X, da Constituição Federal, pura e simplesmente propõe substituí-lo por outro texto, com o que se lhe confere o tratamento de "norma pura", fazendo-o de "letra morta" e reduzindo-o a um mero texto linguístico, comparável às disposições do Código de Hamurabi em relação ao qual, e no contexto atual, não possui, em linguagem mülleriana, qualquer âmbito normativo. Dizendo de outro modo: a decisão em foco contraria Nelson Saldanha, citado por Lenio Streck, que assevera que o texto da norma não se reduz a um mero

${ }^{69}$ MÜLLER, Friedrich. Teoria Estruturante do Direto. São Paulo, SP: Revista dos Tribunais, 2008, p. 192-193. Crê-se que ele está a referir a uma norma total e absolutamente abstrata, no sentido de que nunca será aplicada por absoluta falta de meios materiais e por ser impossível, diferentemente de uma norma que, embora em dado momento não seja aplicada num caso concreto, dela não se pode dizer que é uma norma totalmente abstrata, à medida que pode ser objeto de interpretação, o que é suficiente para retirá-la do limbo em que são jogadas as normas absolutamente abstratas ou totalmente puras.

${ }^{70}$ MÜLLER, Friedrich. Teoria Estruturante do Direto. São Paulo, SP: Revista dos Tribunais, 2008, p. 193.

${ }^{71}$ MÜLLER, Friedrich. Teoria Estruturante do Direto. São Paulo, SP: Revista dos Tribunais, 2008, p. 193. 
enunciado linguístico, o que ocorre quando não se relaciona com algum conteúdo (âmbito normativo), seja porque este não existe mais (a exemplo das disposições do Código de Hamurabi), seja porque não há mínima correspondência entre texto e conteúdo (a exemplo de se pretender conteúdo poético em um decreto). ${ }^{72}$

Para Müller, "com a perda do âmbito normativo, a disposição perde sua normatividade, e o texto original da norma passa a ser apenas texto linguístico, embora a ideia fundamental e o âmbito normativo continuem sendo lingüisticamente 'dados' e embora a ideia normativa fundamental não tenha sido alterada quando quisemos entendê-la de modo independente do dado real como puro dever-ser."73 Ora, no caso em tela não há nenhuma garantia, ou pelo menos suspeita, de que o texto da norma posta no art. 52, X, da Constituição Federal, tenha perdido seu âmbito normativo. Ou seja, não há qualquer indício de que o âmbito normativo, a que o texto da norma serve de suporte ao mesmo tempo em que nele encontra sua justificativa (o ser será sempre o ser de um ente e o ente só existe no seu ser), deixou de existir.

O que aqui se referencia, como homenagem e por integrar a tradição constitucional brasileira, está diretamente relacionado ao princípio democrático, à cláusula pétrea da separação dos poderes e à soberania exercida pelo povo diretamente ou por meio de seus representantes. Nesse sentido, a competência conferida pelo constituinte originário ao Senado Federal de suspender a eficácia de lei declarada inconstitucional pelo STF atende justamente a essa realidade (tradição, âmbito normativo), por força da qual, segundo o paradigma do Estado Democrático, não é dado ao STF o direito de invadir a esfera de outro poder estatal nem o de se transformar em poder constituinte derivado permanente.

Como é que, a partir de um texto (o atual inciso $X$ do artigo 52 da Constituição Federal) se chega a outro (o do voto do Ministro Eros Grau) que não guarda qualquer relação com a norma em questão (necessidade de participação do Senado Federal) e subverte toda uma tradição de controle difuso de constitucionalidade? Com efeito, dizem Lemos, et. al., que "é sabido que, no Brasil, a intervenção do Senado, prevista no art. 52, X, da CF de 1988, tem uma função democrática: a de fortalecer o sistema de freios e contrapesos (checks and balances) na relação interinstitucional

${ }^{72}$ STRECK, Lenio Luiz. A Diferença Ontológica (entre Texto e Norma) como blindagem contra o Relativismo no Processo Interpretativo: uma análise a partir do Ontological Turn. Revista Brasileira de Estudos Políticos, Vol. 89, 2004, p. 130.

${ }^{73}$ MÜLLER, Friedrich. Teoria Estruturante do Direto. São Paulo, SP: Revista dos Tribunais, 2008, p. 218. 
entre os três poderes da República". ${ }^{74}$ Assim, a tarefa do Senado, em sede de controle difuso de constitucionalidade, é a de suspender a norma declarada inconstitucional, efetivando-a e conferindo-lhe teor democrático.

Para Streck, Cattoni de Oliveira e Lima, a mutação constitucional, da forma como proposta no voto do relator e de Eros Grau na Recl. 4.3355/AC, é uma forma de substituir o Poder Constituinte Reformador pelo Poder Judiciário, pois nenhum dos controles de constitucionalidade (concentrado ou misto) prescinde, em homenagem ao princípio democrático, da participação da sociedade. Se no controle concentrado essa participação se manifesta na ampliação da base de legitimidade para a propositura da ADI, no difuso ela ocorre, de forma indireta, na atribuição conferida ao Senado Federal. ${ }^{75}$

Aliás, do voto do Ministro Sepúlveda Pertence, proferida no referido julgamento, lê-se que o papel exercido pelo Senado Federal no controle difuso de constitucionalidade é da tradição constitucional brasileira e dever ser mantido, embora, segundo o Ministro Eros Grau, ela teria sido preservada, dado que o texto resultante da pretendida mutação constitucional se lhe adequaria, o que não deixa de ser contraditório, eis que a mudança proposta significa justamente o contrário: faz tábula rasa da harmonia e separação entre os poderes e da participação democrática em matéria de controle difuso de constitucionalidade. Para Pedron ${ }^{76}-\mathrm{e}$

${ }^{74}$ LEMOS, Tayara Talita, et. al.. Mutação Constitucional e Democracia: uma (des)construção hermenêutica do problema da intervenção do Senado em sede de Controle Difuso de Constitucionalidade. Anais do IX Simpósio Nacional de Direito Constitucional da ABDConst. Curitiba, PR; ABDConst, 2011, p. 377. Disponível em: $<$ http://www.abdconst.com.br/revista3/franca.pdf $>$. Acesso em: 10 de agosto de 2017. 75 "Excluir a competência do Senado Federal - ou conferir-lhe apenas um caráter de tornar público o entendimento do Supremo Tribunal Federal - significa reduzir as atribuições do Senado Federal à de uma Secretaria de divulgação intra-legislativa das decisões do Supremo Tribunal Federal; significa, por fim, retirar do processo de controle difuso qualquer possibilidade de chancela dos representantes do povo deste referido processo, o que não parece ser sequer sugerido pela Constituição da República de 1988." LIMA, Martônio Mont'Alverne Barreto; STRECK, Lenio Luiz; CATTONI DE OLIVEIRA, Marcelo Andrade. A Nova Perspectiva do Supremo Tribunal Federal sobre o Controle Difuso: Mutação Constitucional e Limites da Legitimidade da Jurisdição Constitucional. Argumenta Journal Law, No. 7, 2007, p. 7.

${ }^{76}$ PEDRON, Flávio Barbosa Quinad. A Mutação Constitucional na crise do Positivismo Jurídico: história e crítica do conceito no marco da Teoria do Direito como Integridade. 228 f. 2011. Tese (Doutorado em Direito), Programa de Pós- 
aqui se imagina que o autor se refira ao pressuposto de que prevaleça o entendimento esposado também pelo relator Ministro Gilmar Mendes a posição assumida pelo STF demonstra uma faceta decisionista da função jurisdicional, sobretudo no exercício da jurisdição constitucional, que se dá de forma hipertrofiada, com a avocação de uma legitimidade duvidosa e com uma tendência de se transformar naquilo que Streck, Cattoni de Oliveira e Lima chamam de poder constituinte derivado permanente. ${ }^{77}$

Streck diz que é necessário ter clara a ideia de que o sentido não é algo que pode ser imposto a um objeto. Ao reverso, "os sentidos são atribuíveis a partir da faticidade em que está inserido o intérprete", de sorte que "a norma será sempre, assim, resultado do processo de atribuição de sentido (Sinngebung)" de um texto, que "não subsiste como 'um ente disperso' no mundo", pois "o texto só é em sua norma"."78

Poder-se-ia, em defesa do entendimento firmado na Reclamação em objeto, sustentar que se deu a incorporação da técnica da disapplication típica da jurisdição constitucional estadunidense - à jurisdição constitucional brasileira. Por meio desta técnica o Judiciário transforma em "leis mortas" (dead laws) aquelas leis que não forem, expressamente, contrárias ao texto constitucional, mas que em alguma medida não encontram mais aplicabilidade no mundo dos fatos. A lei continuaria em vigor, mas seria ineficaz. Ocorre que isto é incompatível com uma tradição jurídico-constitucional que não seja, notadamente, de common law. Ademais, mesmo nos EUA fala-se há mais de século que a disapplication pode ser empregada em relação a normas infraconstitucionais, pois as normas constitucionais, devido à técnica adotada pelo Constituinte, em 1787 , já seriam por si mesmas de conteúdo aberto às ressignificações por parte dos intérpretes constitucionais. ${ }^{79}$ Vê-

Graduação da Faculdade de Direito, Universidade Federal de Minas Gerais, Belo Horizonte, MG, 2011, p. 56.

${ }_{77}$ LIMA, Martônio Mont'Alverne Barreto; STRECK, Lenio Luiz; CATTONI DE OLIVEIRA, Marcelo Andrade. A Nova Perspectiva do Supremo Tribunal Federal sobre o Controle Difuso: Mutação Constitucional e Limites da Legitimidade da Jurisdição Constitucional. Argumenta Journal Law, No. 7, 2007, p. 45-68.

${ }^{78}$ STRECK, Lenio Luiz. A Diferença Ontológica (entre Texto e Norma) como blindagem contra o Relativismo no Processo Interpretativo: uma análise a partir do Ontological Turn. Revista Brasileira de Estudos Políticos, Vol. 89, 2004, p. 135 (grifos no original).

79 Sobre o tema, ver CORWIN, Edward. The Supreme Court and Unconstitutional Acts of Congress. Michigan Law Review, Vol. 4, 8, 1906; bem como SUNSTEIN, Cass.

Foreword: Leaving Things Undecided. Harvard Law Review, Vol. 110, 1, 1996, p. 06-

3 JOURNAL OF INSTITUTIONAL STUDIES 1 (2017) 
se, então, que o Direito Constitucional Comparado não se presta a sustentar os argumentos da Reclamação em questão.

Em meio a tantos outros julgados do STF que poderiam ter sido examinados aqui, tomou-se o caso em comento apenas para ilustrar como um paradigma filosófico subjetivista e com raízes genuinamente modernas encontra amplo espaço na jurisdição constitucional brasileira. A superação da literalidade da norma - esta tida como um dos limites mais básicos à interpretação e, por consequência, à mutação constitucional informal - é superada em proveito do dito compromisso de zelar pela guarda da Constituição. $\mathrm{O}$ choque entre tempo e norma constitucional torna-se flagrante.

Voltando a Ost, o jurista belga recorda que toda temporalidade que absolutiza é virtualmente desinstituinte, mesmo no tempo do questionamento: "Se o questionamento e a abertura do futuro libertam das antigas coerções, eles podem também significar desagregação de nossa capacidade coletiva de articular valores comuns, construir montagens simbólicas que distribuam os papéis e os lugares, imaginar instituições portadoras de integração." 80 Para Ost, há lugar para o questionamento, mas ele não deve comprometer a capacidade de fazer e cumprir as promessas. ${ }^{81}$

Uma das promessas assumidas, por ocasião da promulgação da Constituição de 1988, foi a de instituir um Estado Democrático, o que pressupõe: 1) o respeito e a defesa da Constituição como o único documento capaz de, ao mesmo tempo, controlar o exercício dos poderes políticos e garantir as liberdades fundamentais; 2) a observância da separação dos poderes, o que sequer pode ser objeto de emenda à Constituição (art. 60, § $4^{\circ}$, III, CF), sendo vedada a invasão de competência de um poder por outro; e 3) participação democrática da sociedade nos destinos da nação com base no princípio fundante da soberania. É certo que, embora o Ministro Eros Grau diga, em seu voto, que de ordinário as mãos do Judiciário não alcançam o céu, sendo equivocada a suposição de que não se colocam limites ao poder de uma Suprema Corte, verifica-se que na Recl. 4.335-5/AC defende abertamente que o jogo termina com o último lance do STF, caso em que, segundo ele, "nossos braços então alcançam o céu."

Ocorre que uma decisão desta natureza se olvida que, a par de se constituir em guardião da Constituição, o Tribunal Constitucional deve

101; e CICCONETTI, Stefano; TEIXEIRA, Anderson Vichinkeski. Jurisdição

Constitucional Comparada. Florianópolis, SC: Conceito Editorial, 2010, Cap. 4.

${ }^{80}$ OST, François. O Tempo do Direito. Bauru, SP: Edusc, 2005, p. 307-308.

${ }^{81}$ OST, François. O Tempo do Direito. Bauru, SP: Edusc, 2005, p. 308. 
agir sob o seu comando e não sobre ela. Na matéria em questão, por expressa vontade da norma constitucional (art. 52, X), o jogo é decidido em dois tempos, não havendo como sustentar que, na hipótese, o Supremo tem a última palavra. Não se trata, por óbvio, de um lance individual, mas de uma construção coletiva em que o jogo é jogado de forma compartilhada. ${ }^{82}$

Uma evolução normativa por intermédio da interpretação constitucional deve ter por objeto uma norma de conteúdo abstrato (dignidade humana, por exemplo) ou uma norma com conteúdos múltiplos que permita a sua ressignificação (liberdade, por exemplo, pois já foi tantas vezes redefinida na jurisprudência do STF). Decidir contra expressa disposição literal de norma constitucional vai muito além de uma evolução normativa: constitui evidência de uma patologia constitucional existente dentro do sistema. A grande questão, em situações assim, é verificar se a patologia está na decisão em si ou em um mecanismo do sistema de equilíbrio entre poderes que se mostra falho. Uma hipotética sociedade de demônios pode esconder seus vícios em pequenas práticas voltadas ao equilíbrio entre poderes, como uma regra que determina o mínimo de deferência por parte de um poder a outro que decidiu em determinado sentido acerca da inconstitucionalidade de uma

${ }^{82}$ A reclamação foi julgada procedente por maioria de votos, prevalecendo assim o entendimento do Ministro Relator Gilmar Mendes e do Ministro Eros Grau, que votaram pela procedência ao argumento de que se operara o fenômeno da mutação constitucional, visto que a regra constitucional que remete ao Senado a suspensão da execução de dispositivo legal ou de toda lei declarada inconstitucional pelo STF tem efeito de mera publicidade, pois as decisões da Corte sobre a inconstitucionalidade de leis têm eficácia normativa, mesmo que tomadas em ações de controle difuso. $\mathrm{Na}$ mesma ocasião, o Ministro Sepúlveda Pertence deu-a por improcedente. O Ministro Joaquim Barbosa, que também rejeita a tese de mutação constitucional informal contra legem, votou pela extinção do processo sem julgamento do mérito, por entender que os pressupostos processuais do feito não se fizeram presentes. Já o Ministro Ricardo Lewandowski não conheceu da Reclamação. O processo estava suspenso desde 16.05.2013, por força de pedido de vista do Ministro Teori Zavascki que, na data de 28.08.2013, devolveu os autos e na sessão plenária do dia 20.03.2014 o julgamento foi retomado. Em seu voto-vista, Zavascki sustentou que, embora o artigo 52, inciso X, da Constituição estabeleça que o Senado deve suspender a execução de dispositivo legal ou da íntegra de lei declarada inconstitucional por decisão definitiva do STF, as decisões daquela Corte, ao longo dos anos, têm-se revestido de eficácia expansiva, mesmo quando tomadas em controvérsias de índole individual. O referido voto foi acompanhado pelos Ministros Luís Roberto Barroso, Rosa Weber e Celso de Mello. A decisão foi publicada no DJE n 208, em 20/10/2014.

3 JOURNAL OF INSTITUTIONAL STUDIES 1 (2017) 
matéria; todavia, a existência de uma regra como esta, desprovida de qualquer sanção, pode vir a não ser obedecida por puro voluntarismo político ou mesmo por desprezo ao poder que emanou a decisão. Como o objeto desta pesquisa não é o princípio da separação de Poderes, devese aqui apenas suscitar a questão sem maiores aprofundamentos. Tratarse-ia de uma tema de Sociologia Constitucional ou Ciência Política.

Antes de encerrar, não há como esquecer de reforçar a advertência de Ost: nem o tempo petrificado, que não abre possibilidade de mudança, nem o tempo exageradamente móvel, que não propicia espaço para a continuidade. Em ambos os casos, o risco de eliminar a força normativa da Constituição é uma presença constante. É preferível correr em busca da justa medida temporal.

\section{CONSIDERAÇÕES FINAIS}

François Ost diz que o tempo é instituinte do direito, enquanto que Konrad Hesse afirma que toda Constituição é Constituição no tempo. Streck, fechando essa equação, assevera que os sentidos são temporais e qualquer tentativa de negar a norma como produto da interpretação do texto e a interpretação como um ato aplicativo equivale a negar a temporalidade. Müller diria que norma e conteúdo são indissociáveis no espaço e no tempo.

Para Ost, nenhuma história é mais representativa da negativa do tempo que a de Kronos: ao decepar com um machado os genitais do pai, Urano, e engolir os próprios filhos, desliga, simultaneamente, passado e futuro, constituindo-se senhor do tempo, limitado, contudo, ao instantâneo e estéril presente, porque sem memória (passado) e sem projeto (futuro). Licurgo quis manter viva a memória, amarrando-se ao passado, e sonhou que, morrendo, manteria o futuro para sempre desligado.

Ost não vê nenhuma dificuldade em perceber o mundo atual como mais complexo do que no século 19 - e infinitamente mais do que antes de Cristo, acrescente-se. ${ }^{83} \mathrm{Com}$ isso, o jusfilósofo belga pretende dizer que na contemporaneidade e em plena sociedade de risco não se concebe mais que um legislador, tomado pelo espírito de Licurgo, pretenda embalar-se com o sonho da perenidade das leis. Segue-se que adaptar o texto normativo (e por que não a própria norma que o texto carrega?) às circunstâncias cambiantes, submetendo-o, de forma regular, à avaliação

${ }^{83}$ OST, François. O Tempo do Direito. Bauru, SP: Edusc, 2005, p. 301. 
(popular, por exemplo), agregando-se, ainda, para enriquecer, as boas lições da jurisprudência e da doutrina, tudo isso são formas de "questionamento" (retomada da discussão) perfeitamente legítimas. Nesse sentido, "Não estamos seguros, contudo, de que a mutabilidade contemporânea da lei derive sempre desse cuidado de harmonizar as promessas; em casos demasiadamente numerosos, ela é, antes, explicada pela ação desinstituinte dos interesses particulares ${ }^{84}$ e a dificuldade de decidir nos regimes assediados pelas forças centrífugas dos lobbies." 85

No mesmo sentido, Konrad Hesse reconhece que a realidade social, refletida nas normas constitucionais, se submete às mudanças históricas, que também afetam o conteúdo das Constituições. ${ }^{86} \mathrm{E}$ alerta para o fato de que, quando as mudanças históricas são ignoradas, o conteúdo constitucional "fica petrificado" e, a curto ou longo prazo, não poderá cumprir suas funções (as promessas assumidas pelo Constituinte), também frustradas se a adaptação às circunstâncias momentâneas se fizer sem qualquer tipo de reserva. Sucede, nesse caso, que a Constituição não tem mais força para pautar a ordem dia, quando então as circunstâncias é que irão imprimir o rumo dos acontecimentos.

Não se ignora, contudo, que as Constituições possuem mecanismos de proteção que podem ser opostos às circunstâncias, mas isso ocorre somente em parte, eis que o quesito das maiorias qualificadas pode ser superado. Em ambos os casos (passado sempre ligado ou futuro ligado sem qualquer tipo de controle), Hesse esclarece que "a força dos fatos se revela superior ao poder do Direito; no primeiro caso, o tempo deixa defasada a Constituição e, no segundo, a degrada até reduzi-la a mero reflexo das relações de poder existentes em cada momento" ${ }^{\prime 87}$

Conclui então afirmando que:

Por isso, da perspectiva de Constituição no tempo, a Constituição só pode cumprir suas tarefas onde consiga, sob mudadas circunstâncias, preservar sua força normativa, isto é, onde consiga garantir sua continuidade sem prejuízo das transformações históricas, o que pressupõe a conservação de sua identidade. Partindo disso, nem a Constituição com um todo nem suas normas concretas podem ser concebidas como letra morta, como algo estático e rígido;

${ }^{84} \mathrm{Um}$ bom exemplo é quando isso se dá em nome das efetividades quantitativas.

${ }^{85}$ É o caso de uma ordem jurídica que se deixa cada vez mais se pautar pelo mercado e pelo interesse financeiro das grandes corporações.

${ }^{86}$ HESSE, Konrad. Temas Fundamentais do Direito Constitucional. Trad. Gilmar Ferreira Mendes. São Paulo, SP: Saraiva, 2013, p. 13-14.

${ }^{87}$ HESSE, Konrad. Temas Fundamentais do Direito Constitucional. Trad. Gilmar Ferreira Mendes. São Paulo, SP: Saraiva, 2013, p. 13-14.

3 JOURNAL OF INSTITUTIONAL STUDIES 1 (2017) 
precisamente sua continuidade pode chegar a depender da forma em que se encare a mudança. ${ }^{8} 8$

Ost diz que, como nenhuma sociedade fica indiferente aos seus temores advindos do passado (quando a condena a perpetuar-se eternamente) ou do futuro (quando não deixa nenhuma margem de previsibilidade, privando-a de qualquer referência), forja mecanismos destinados a desligar o passado e a ligar o futuro, num exercício permanente de acomodações. ${ }^{89}$ A relação entre Temperança, com sua ampulheta, e Justiça, com seu Gládio ${ }^{90}$, não é só um jogo de palavras que não diz algo de algo. O direito é filho dessa relação. E direito, como ensina Ost, é medida pelo menos em quatro sentidos. ${ }^{91}$ É decisão e é regra de conduta, mas é também o próprio instrumento que mede a medida e equilíbrio, moderação, justo meio termo e prudência, sem falar de um quarto sentido, traduzido na ideia de temperança:

Em seu trabalho de ajuste permanente, a medida jurídica é ritmo - o ritmo conveniente, a harmonia das durações diversificadas, a escolha do momento oportuno, o tempo atribuído à marcha social medida. Lenta em demasia, esta medida provoca frustrações e nutre as violências do futuro: rápida em demasia, ela gera a insegurança e desencoraja a ação. Esta é, portanto, a medida do direito: norma, proporção, limite e ritmo. ${ }^{92}$

E há mesmo que ser assim, afinal nem sempre teremos à disposição um Zeus para, vingando-se de Kronos, religar passado e futuro e unir ambas as pontas no presente, tornando-o fértil. Presente que é a justa medida dos dois tempos misturados, que é onde se desenvolve a medida do direito em todos os seus sentidos, ainda que instantâneo e efêmero. Presente que funciona como a embreagem do tempo, cuja ação, tal qual a de um veículo automotivo com câmbio mecânico, só dura o necessário à mudança da marcha (ou da contramarcha). Mas, é nele que, feliz ou infelizmente, nos movemos.

${ }^{88}$ HESSE, Konrad. Temas Fundamentais do Direito Constitucional. Trad. Gilmar Ferreira Mendes. São Paulo, SP: Saraiva, 2013, p. 14.

${ }^{89}$ OST, François. O Tempo do Direito. Bauru, SP: Edusc, 2005, p. 38.

${ }^{90}$ Referência ao afresco A alegoria do bom e do mau governo, do pintor italiano Ambrogio Lorenzetti, que François Ost descreve em $O$ tempo do direito. OST, François. O Tempo do Direito. Bauru, SP: Edusc, 2005, p. 12.

${ }^{91}$ OST, François. O Tempo do Direito. Bauru, SP: Edusc, 2005, p. 399.

${ }_{92}$ OST, François. O Tempo do Direito. Bauru, SP: Edusc, 2005, p. 400. 


\section{REFERÊNCIAS}

BARATA, Rodrigo Sarmento. A Mutação Constitucional e o STF: sua utilização e algumas perspectivas. In: Adriana Vojvodic; Henrique Motta Pinto; Paula Gorzoni; Rodrigo Pagani de Souza (Orgs.).

Jurisdição Constitucional no Brasil. São Paulo, SP: Malheiros, 2012.

BULOS, Uadi Lammêgo. Mutação constitucional. São Paulo, SP:

Saraiva, 1997.

CARVALHO, Renan Flumian de. Qual é o conceito de Mutação

Constitucional para os Ministros do STF? 69 f. 2009. Monografia

(Bacharelado em Direito), Escola de Formação, Sociedade Brasileira de Direito Público, São Paulo, SP, 2009. Disponível em:

$<$ http://www.sbdp.org.br/arquivos/monografia/138 Monografia\%20Ren an.pdf $>$. Acesso em: 10 de agosto de 2017.

CICCONETTI, Stefano; TEIXEIRA, Anderson Vichinkeski. Jurisdição Constitucional Comparada. Florianópolis, SC: Conceito Editorial, 2010.

CORWIN, Edward. The Supreme Court and Unconstitutional Acts of Congress. Michigan Law Review, Vol. 4, 8, 1906.

FERRAZ, Ana Cândida da Cunha. Processos Informais de Mudanças da Constituição: Mutações Constitucionais e Mutações Inconstitucionais. São Paulo, SP: Max Limonad, 1986.

GRAU, Eros Roberto. A Ordem Econômica na Constituição de 1988. São Paulo, SP: Malheiros, 1998.

HÄRBELE, Peter. Hermenêutica Constitucional. A Sociedade Aberta dos Intérpretes da Constituição: contribuição para uma interpretação 
pluralista e "procedimental" da Constituição. Trad. Gilmar Ferreira Mendes. Porto Alegre, RS: Sérgio Antonio Fabris, 1997.

HESSE, Konrad. Temas Fundamentais do Direito Constitucional. Trad. Gilmar Ferreira Mendes. São Paulo, SP: Saraiva, 2013.

LEMOS, Tayara Talita, et. al.. Mutação Constitucional e Democracia: uma (des)construção hermenêutica do problema da intervenção do Senado em sede de Controle Difuso de Constitucionalidade. Anais do IX Simpósio Nacional de Direito Constitucional da ABDConst. Curitiba, PR; ABDConst, 2011. Disponível em: $<$ http://www.abdconst.com.br/revista3/franca.pdf $>$. Acesso em: 10 de agosto de 2017.

LIMA, Martônio Mont'Alverne Barreto; STRECK, Lenio Luiz; CATTONI DE OLIVEIRA, Marcelo Andrade. A Nova Perspectiva do Supremo Tribunal Federal sobre o Controle Difuso: Mutação Constitucional e Limites da Legitimidade da Jurisdição Constitucional. Argumenta Journal Law, No. 7, 2007.

LUIZ, Fernando Vieira. Teoria da Decisão Judicial: dos paradigmas de Ricardo Lorenzetti à resposta adequada à Constituição de Lenio Streck. Porto Alegre, RS: Livraria do Advogado, 2013.

MENDES, Gilmar Ferreira. O papel do Senado Federal no Controle de Constitucionalidade: um caso Clássico de Mutação Constitucional. Revista de Informação Legislativa, Vol. 41, 162, 2004.

MORAIS, Carlos Blanco de. As Mutações Constitucionais e os seus Limites Jurídicos: autópsia de um acórdão incontroverso. Jurismat, No. 3, 2013.

MÜLLER, Friedrich. Teoria Estruturante do Direto. São Paulo, SP: Revista dos Tribunais, 2008. 
OST, François. O Tempo do Direito. Bauru, SP: Edusc, 2005.

PEDRA, Adriano Sant'Ana. Teoria da Mutação Constitucional: limites e possibilidades das Mudanças Informais da Constituição a partir da Teoria da Concretização. 331 f. 2009. Tese (Doutorado em Direito), Programa de Pós-Graduação, Pontifícia Universidade Católica de São Paulo, São Paulo, SP, 2009 (Também publicado como Mutação

Constitucional: Interpretação Evolutiva da Constituição na Democracia Constitucional. Rio de Janeiro, RJ: Lumen Juris, 2014).

PEDRON, Flávio Barbosa Quinad. A Mutação Constitucional na crise do Positivismo Jurídico: história e crítica do conceito no marco da Teoria do Direito como Integridade. 228 f. 2011. Tese (Doutorado em Direito), Programa de Pós-Graduação da Faculdade de Direito, Universidade Federal de Minas Gerais, Belo Horizonte, MG, 2011.

PLUTARCO. A Vida de Licurgo. 884 a.C.

SALDANHA, Nelson. Racionalismo jurídico, crise do legalismo e problemática da norma. Anuário dos Cursos de Pós-Graduação em Direito da UFPE, No. 10, 2000.

SANTOS, Carlos Victor Nascimento dos. Reconstruindo o conceito de Mutação Constitucional. RECHTD: Revista de Estudos Constitucionais, Hermenêutica e Teoria do Direito, Vol. 7, 1, 2015.

SILVA, Vírgilio Afono da. “Um Voto Qualquer?" O papel do Ministro Relator na Deliberação do Supremo Tribunal Federal. Revista de Estudos Institucionais, Vol. 1, 1, 2015.

STRECK, Lenio Luiz. O que é isto - decido conforme minha consciência? 4ª ed. Porto Alegre, RS: Livraria do Advogado, 2013. 
. A Diferença Ontológica (entre Texto e Norma) como blindagem contra o Relativismo no Processo Interpretativo: uma análise a partir do Ontological Turn. Revista Brasileira de Estudos Políticos, Vol. 89, 2004.

SUNSTEIN, Cass. Foreword: Leaving Things Undecided. Harvard Law Review, Vol. 110, 1, 1996.

Mutação Constitucional como Evolução Normativa ou Patologia Constitucional?

Tempo e Direito à Luz da Hermenêutica-Filosófica Constitutional Mutation as Normative Evolution or Constitutional Pathology? Time and Law in the light of Hermeneutic-Philosophical Submetido em: 2017-01-25 Aceito em: 2017-07-29 